\title{
THE USE OF ALTERNATIVE METHODS FOR DIFFERENTIATION OF BANDED IRON FORMATIONS AND IRON ORE IN THE BODY N4WS, SERRA NORTE - CARAJÁS MINERAL PROVINCE
}

\author{
Vitor Nascimento Ferreira ${ }^{1}$, Adalene Moreira Silva ${ }^{1}$, Catarina Laboué Benfica Toledo ${ }^{1}$, \\ Marta Henriques Jácomo², Luciano Mozer de Assis ${ }^{3}$ and Augusto César Bittencourt Pires ${ }^{4}$
}

\begin{abstract}
The use of non-traditional geophysical methods is becoming increasingly common in activities involving iron ore, as the increasing ore demand intensified the competition in the international market. This motivated us to integrate the physical properties of the rocks to better understand the relations of the iron ore with the proto-ore and host rocks. The work was conducted in N4WS body, Serra Norte, Carajás Mineral Province (CMP), located in the state of Pará, Brazil. The Carajás Mineral Province hosts some of the largest world-class iron ore deposits operated by Vale S.A. The results of airborne magnetic data showed that the mineralized bodies previously mapped are not directly linked to the high gradients observed in the amplitude of the analytic signal. This response is related to the proto-ore, constituted by jaspilites with low values of $\mathrm{K}$, eU and eTh. Measurements of the magnetic susceptibility and gamma radiation emission in drill holes were satisfactory. There was a clear differentiation between iron ore, jaspilites and mafic rocks, mainly in the magnetic susceptibility parameter. The gamma-ray results from radioelements separated iron formations and associated mineralization from the adjacent mafic rocks. The use of the non-supervised classification k-means was useful for distinguishing between jaspilites within the same package and to show anomalous areas not previously mapped. The integration of rock physical properties, geological data and airborne geophysical data produced excellent results. There was a direct correlation between what was measured and what was observed in situ at the surface. Thus, it was possible to individualize the lithotypes in the N4WS using the physical properties. This confirms the feasibility of using these methods as an alternative to the currently used tools for iron ore exploration, with the potential to increase the efficient use of human and financial resources investments.
\end{abstract}

Keywords: multisource data integration, jaspilites, gamma-ray spectrometry, rock physical properties.

RESUMO. A utilização de métodos geofísicos não tradicionais está se tornando cada vez mais comum em atividades que envolvem o minério de ferro, uma vez que a alta demanda impulsiona o mercado internacional. Este avanço nos leva a integrar a assinatura das propriedades físicas de rocha para melhor entendimento do minério de ferro com o protominério e suas rochas adjacentes. 0 trabalho foi realizado no corpo N4WS, Serra Norte, Província Mineral de Carajás (CMP), Iocalizado no estado do Pará. A Província Mineral de Carajás abriga alguns dos maiores depósitos de minério de ferro de classe mundial, todos explorados pela Vale S.A. Os resultados dos dados aeromagnéticos mostraram que os corpos mineralizados previamente mapeados não possuem uma ligação direta com os gradientes elevados observados na amplitude do sinal analítico. Esta resposta é relacionada ao protominério, constituído por jaspilitos de assinatura gamaespectrométrica relacionados aos baixos valores de $\mathrm{K}$, eU e eTh. As respostas das medidas de susceptibilidade magnética e emissão de radiação gama realizadas nas sondagens dentro do prospecto foram satisfatórias. Houve uma clara diferenciação entre o minério de ferro, jaspilitos e rochas máficas, principalmente no parâmetro susceptibilidade magnética. Os resultados da gamaespectrometria separaram as formações ferríferas e minério das rochas máficas adjacentes. 0 uso da classificação não-supervisionada K-médias foi útil para distinção entre jaspilitos dentro do mesmo pacote e identificação de áreas anômalas não mapeadas anteriormente. A integração entre propriedades físicas de rocha, dados geológicos e dados aerogeofísicos mostrou excelentes resultados. Houve uma correlação direta entre o que foi medido e observado in situ na superfície. Dessa forma, foi possível individualizar os litotipos em N4WS utilizando as propriedades físicas de rocha. Isto confirma a viabilidade dos métodos aplicados como uma alternativa para as ferramentas utilizadas atualmente na exploração de minério de ferro, com o potencial para aumento da eficiência dos recursos humanos e investimentos financeiros.

Palavras-chave: integração de dados multifonte, jaspilitos, gamaespectrometria, propriedades físicas de rocha.

\footnotetext{
${ }^{1}$ Universidade de Brasília, Instituto de Geociências, Campus Universitário Darcy Ribeiro, Asa Norte, Brasília, DF, Brazil - E-mails: vitor.geo.ferreira@gmail.com; adalene@unb.br; catarinatoledo@unb.br

2Universidade de São Paulo, IAG - USP, Rua do Matão 1226, 05508-090 São Paulo, SP, Brazil - E-mail: marta.jacomo@iag.usp.br

3 Vale S.A., Mina de Águas Claras, Avenida de Ligação, n.3580, 34000-000 Nova Lima, Minas Gerais, Brazil - E-mail: luciano.assis@vale.com

${ }^{4}$ Agência para o Desenvolvimento da Indústria Mineral Brasileira (ADIMB), Brasília, DF, Brazil. Phone: +55(61) 3326-0759 - E-mail: abcpires@unb.br
} 


\section{INTRODUCTION}

Iron ore is currently the highest mineral asset in the Brazilian trade balance, with a growing importance in the national markets. Brazilian reserves, despite corresponding to $16.4 \%$ of the world reserves, are highlighted by the high grade of iron with particular reference to the production in the Carajás Mineral Province. The Carajás District contains known reserves of the order of 18 billion tons with an average grade of $65.4 \% \mathrm{Fe}$. The reserves are distributed in a number of deposit groups, wherein the largest one is the Serra Norte deposit with $-6,200 \mathrm{Mt} 65.8 \% \mathrm{Fe}$. This ore can be blended together with low grade ores in diverse/various parts of the world.

Despite its importance, only during the last decade, there were significant advances in the application of geophysical methods (e.g. Dalstra \& Flis, 2008; Flis, 2008; Braga, 2009) to iron ore characterization. Large companies are demanding the use of innovating tools to reduce costs.

Among the main advantages of the geophysical methods, stand out the agility in the acquisition, processing and interpretation of data when compared to direct drilling and the continuous information provide by these methods. However, their main disadvantage is the ambiguity of results, which often can be solved by the integration of different geophysical methods, or even, by using information of a few drill holes for result validation.

To understand the behavior of iron ore and its host rocks, this work aims to characterize the jaspilites, iron ore and adjacent rocks using the rock physical properties of magnetic susceptibility and gamma-rays spectrometry ( $\mathrm{K}$, eTh and eU). The data integration allowed and highlighted the important physical contrast inside the Grão Pará Group.

The study area is located in the Serra Norte, Carajás Mineral District (Fig. 1), within the limits of the Carajás National Forest, in the county/city of Parauapebas, Pará State. This mining district, exploited by Vale S.A., is represented by the N4 and N5 open pits, and the deposits N1 to N3 and N6 to N9. The thickness of the mineralized package varies between 250 and $300 \mathrm{~m}$, with lengths from $200 \mathrm{~m}$ (N3, N6, N7 and N9) up to $10 \mathrm{~km}$ (N4) and it can reach up to $600 \mathrm{~m}$ deep (down dip). The N4WS prospect is still in pre-exploration phase and it will be the target of the present study.

\section{GEOLOGICAL SETTING}

The Carajás Mineral Province (CMP) is located in the easternsoutheastern portion of the Amazon Craton and is divided into two Archean tectonic blocks: the southern Rio Maria granitegreenstone terrain (Huhn et al., 1988) and the north area, which is called Carajás (Fig. 1). The Rio Maria Domain is characterized by a juvenile Mesoarchean crust, with sequences of greenstone belts and TTG-type granitoids. In contrast, Carajás Domain is predominantly Neoarchean, characterized mainly by metavolcanicsedimentary sequences and high- $\mathrm{K}$ granitoids. Both domains are marked by an Osirian A-type granitic magmatism (Vasquez et al., 2008).

The CMP is defined as a polymetallic province due to its huge richness and mineral diversity. It is the most important mineral province in Brazil and one of the most important in the world. It gathers a singular group of mineral deposits, unique in the planet. It hosts one of the largest iron deposits in the world (26 billion of tonnes) still in production and increasing potential for other commodities like $\mathrm{Mn}, \mathrm{Cu}, \mathrm{Au}, \mathrm{Ni}, \mathrm{U}, \mathrm{Ag}, \mathrm{Pd}, \mathrm{Pt}$, Os, among others. There are many noteworthy deposits: iron deposits: Serra Norte (N1 to N9), South (S1 to S45) and east (SL1 to SL3); Fe-CuAu oxide type deposits: Salobo, Pojuca, Alemão, Igarapé Bahia, Cristalino, Sossego, Alvo 118, Gameleira; Azul manganese deposits; and the Vermelho nickel deposits (Lobato et al., 2005).

The oldest Archaean units representing Carajás domain basement, known as Xingu Complex, consist of granitic, tonalitic and trondhjemitic composition gneisses with intercalated amphibolites and tonalitic intrusions (Silva et al., 1974) are aged ca. $2859 \pm 2$ M.y. (U-Pb zircon; Machado et al., 1991), migmatized in ca. $2851 \pm 4$ M.y. (U-Pb zircon; Machado et al., 1991). Small ortogranulite nuclei called Pium Complex aged ca. 3002 \pm 14 M.y. (U-Pb zircon; Pidgeon et al., 2000) may be individualized in the southern portion of the Carajás domain (Araújo \& Maia, 1991). Data available in the literature show that the metamorphism of these rocks has occurred at around $2.8 \mathrm{Ga}$. (Machado et al., 1991; Roberts et al., 1992; Pimentel \& Machado 1994; Pidgeon et al., 2000).

Supracrustal rocks are represented by a succession of volcano-sedimentary rocks, represented by Itacaiúnas Supergroup (DOCEGEO, 1988), which includes the Igarapé Salobo, Igarapé Pojuca, Grão Pará, Igarapé Bahia and Buritirama groups that form the mountains and plateaus of the Carajás region. Among these units, stands out the Grão Pará Group and, within it, the Carajás Formation which consists of jaspilites that host the main iron ore bodies of the province. Besides Carajás Formation, Grão Pará Group also has a mafic volcanic sequence in the base referred to as Parauapebas Formation, and a basic volcanic sequence at the top, known as Igarapé Cigarra Formation (Macambira, 2003; Zuchetti, 2007).

Beisiegel et al. (1973) divided the Grão Pará Group into two paleovolcanic sequences, upper and lower, separated by Carajás 


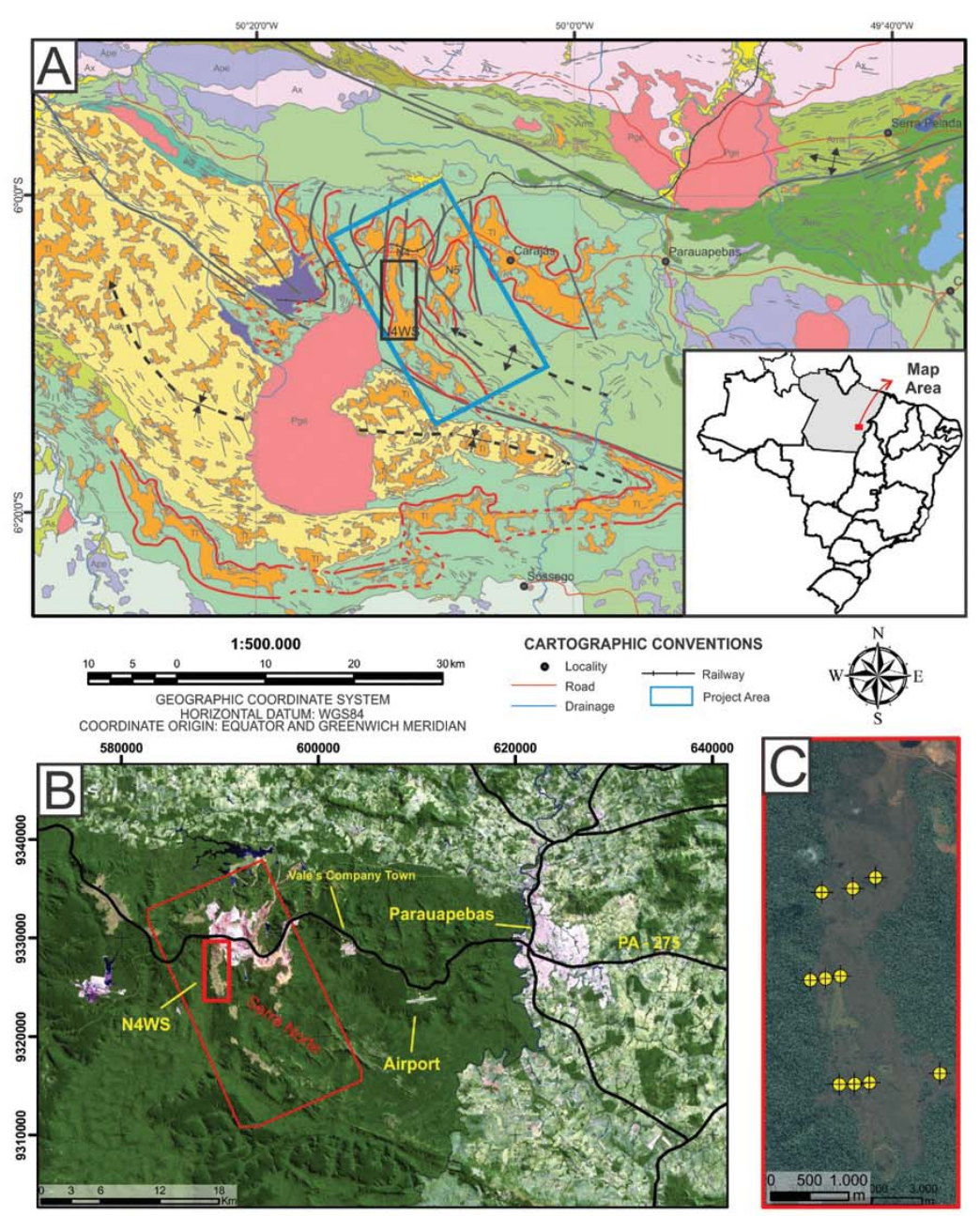

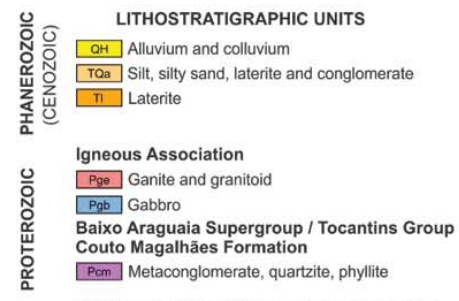

Rio Fresco Group / Aguas Claras Formation Aac Pelite, arcose, sandstone and conglomerate Aacm Manganiferous pelite

Plaque Suite / Estrela Granite / Serra do Rabo Granite Ape Leucogranite, granodiorite and granitoid

Sapucaia Group As basic and ultrabasic volcanic rock

Igarape Pojuca Group , intermediary volcanic rock, Aip pelite and chemical sediments

Grao Para Group

z AgD Quartzite, metabasalt, metariolite, iron formation

Alto and metadacite

Alto Bonito Group

Rio Novo Group

Arns Clast-chemical metasedimentary rock

Amv Basic volcanic rock, iron formation and anfibolite

Undivided Rio Novo Group

Ami Metavolcanic-sedimentary rocks

Luanga Suite

N Norite, gabbro, pyroxenite and serpentinite

Pium Complex

Ap Charnockite, enderbite and basic granulite

Xingu Complex

Ax Dioritic gneiss, metagabbro, meta-ultramafic, orthogneiss, paragneiss, amphibolite, migmatite, granodioritic gneiss,

Undivided Archean

Aind Undifferentiated

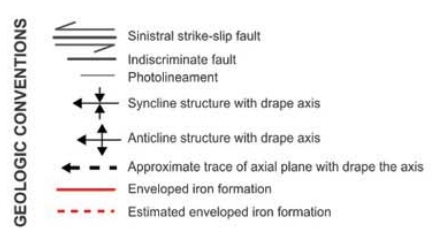

Figure 1 - A - Geological map of the Carajás Mineral Province (Modified from Costa, 2007). B - Location of the work/study area with emphasis on the Serra Norte. Landsat 8 OLI (RGB composition, 764 bands) image. C - N4WS Prospect with the respective drill holes used.

Formation. The lower paleovolcanic sequence named Parauapebas Formation (Rio Doce Geologia e Mineração, 1984) is represented by hydrothermally altered mafic volcanic rocks with primary features preserved. The upper paleovolcanic sequence, corresponding to Igarapé Cigarra Formation (Macambira, 2003; Zucchetti, 2007), consists of basic volcanic rocks similar to those of the Lower Paleovolcanic Sequence, and can be distinguished by lenticular intercalations of iron formation.

The Carajás Formation comprises banded iron formations of jaspilite oxide type facies, with variations related to alterations. It is almost totally transformed in hematitic ore up to a hundred meters deep, cut by mafic dikes and sills. This unit hosts iron ore deposits with an average grade of $66 \%$ iron. It occurs concordant to Paraupebas Formation and Igarapé Cigarra Formation. Carajás Formation has 200-250 m average thickness in Serra Norte (near
$220 \mathrm{~m}$ thickness in the area of the N4E mine) and above $300 \mathrm{~m}$ in Serra Sul (Macambira, 2003). It extends laterally, from plateau N1 to plateau N5 in an almost continuous way. It is covered unconformably by Igarapé Azul Formation between N1 and N2 and interrupted tectonically between N4 and N5 by strike-slip faults. In general, in N4, the dip is to the west and in N5 the strikes of Carajás Formation are displaced by faults and compose a syncline, whose axis dips to SW (Macambira, 2003).

Jaspilites present typical interlayered light and dark bands, with centimetric mesobands and milimetric microbands of ferrous oxide interlayered with brilliant to light red layers. They are constituted by microcrystalline $\mathrm{SiO}_{2}$ (jasper and chert) with inclusions of microcrystalline hematite. Dark mesobands are made up of iron oxides presenting a variety of textures. The dominant thin phases are microcrystalline hematite and martitized magnetite. Granula- 
tion of these rocks are small, with granoblastic texture, sometimes veinlet and brecciated (Beisiegel et al., 1973; Meirelles, 1986; Lindenmayer et al., 2001; Macambira, 2003; Figueiredo \& Silva et al., 2004; Lobato et al., 2005).

Besides compositional banding, Carajás jaspilites preserve many depositional and post-depositional structures, such as spherulites of a probable organic origin, plane parallel lamination, scour-and-fill structures and slump structures, overloading marks, flame structures and dissolution breccias, thatindicate absence of regional metamorphism (Meirelles, 1986; Lindenmayer et al., 2001; Macambira, 2003). The jaspillites have suffered a ruptile to ruptile-ductile deformation, like faults, shear zones and a complex pattern of folds outlined by primary bedding, characteristic structures at shallow crustal level (Vasquez et al., 2008).

The lithochemical composition of the jaspilites is uniform. The sum of $\mathrm{Fe}_{2} \mathrm{O}_{3} \mathrm{~T}$ (total) and $\mathrm{SiO}_{2}$ in Carajás is systematically above $97 \%$ demonstrating high ore purity and absence of terrigenous material. They are interpreted as made up by chemical precipitation in a wide and tectonically stable shallow submarine platform, with possible contribution of fumaroles and/or hydrothermal vents (Lindenmayer et al., 2001a; Macambira \& Schrank, 2002).

The Carajás Formation has an inferred age, determined an metavolcanic rocks concordant to the jaspilites bedding, with intervals between $2740 \pm 8$ and $2757 \pm 18$ M.y. (Trendall et al., 1998; Krymsky et al., 2002). According to Macambira (2003), the maximum deposition interval of this unit is 29 M.y., with maximum age $2759 \pm 2$ M.y. equals to Parauapebas Formation (Machado et al., 1991), and minimal age $2740 \pm 8$ M.y. (Trendall et al., 1998) corresponding to a sill that cuts Carajás Formation.

Deposited over the Grão Pará Group occurs the Águas Claras Formation basin, a sedimentary sequence consisting of conglomerates, sandstones, dolomites/limestones and gray, red and carbonaceous siltstones (Meireles et al., 1982; Meireles \& Silva, 1988; Araújo \& Maia, 1991), with depositional age of circa 2681 \pm 5 M.y. (Trendall, 1998). Souza et al. (2001) suggest that the deposition occurred in a passive continental margin environment as a result of regional strain.

Two main geotectonic models have been proposed for the Grão-Pará Group: which admit evolution associated to continental rift environments or magmatic arcs (Meirelles \& Dardenne, 1991; Teixeira, 1994; Lindenmayer et al., 2005; Lobato et al., 2005; Zucchetti, 2007).

The Parauapebas Formation is represented by basaltic flows, felsic volcanic rocks and mafic intrusions, which occur concordantly over the Carajás Formation both reflecting the same age
(Beisiegel et al., 1973; Macambira, 2003). Mafic rocks include basaltic flows and intrusive rocks like sills and dikes, of basalts, andesitic basalts, andesites, basaltic andesites, traquiandesites, dacites, quartz- diorites, diorites and gabbros (Araújo et al., 1991; Meirelles \& Dardenne, 1991; Macambira, 2003; Lindenmayer et al., 2005; Zucchetti, 2007). They also occur associated to lower basaltic flows with layers of basic to intermediate pyroclastic rocks and volcanoclastics, felsic flows and tuffs described as rhyolites (Meirelles \& Dardenne 1991, Zucchetti \& Lobato 2004). The Parauapebas Formation is dated $2759 \pm 2$ and $2760 \pm 11$ M.y., obtained through U-Pb zircon (Machado et al., 1991; Trendall et al., 1998).

The Igarapé Cigarra Formation was initially designed by Macambira et al. (1990), but it was previously named as Sequência Paleovulcânica Superior (Beisiegel et al., 1973), Unidade Superior (Gibbs et al., 1986). It is also considered Parauapebas Formation by some authors (Vasquez et al., 2008). It has variable thickness from 1 to $3 \mathrm{~km}$, and its contact is still a matter of doubt among many authors (Meirelles \& Dardenne, 1991; Lindenmayer et al., 2001). It is made up of mafic flows with interlayered tuffs, overlain by clastic and chemical sediments like siltites, phylites and graywacke (Gibbs et al., 1986; Macambira, 2003). Among the most frequent lithotypes are hydrothermally altered basalts with preserved igneous textures (Macambira, 2003).

There is still no consensus on the origin of the iron mineralization in the Carajás Mineral Province, even the classification of the local iron formations (Gross, 1980) is not a definite proposal. Beukes et al. (2002) describe in-summary three types of genetic processes for high grade hematite deposits: supergene, hydrothermal and supergene-hydrothermal alteration. The mentioned processes are applied and supported by diverse authors for Carajás Mineral Province, as explained in the following paragraphs.

Supergene iron ore deposits are developed in an area where erosive discordance intercepts carbonate enriched iron formations. High grade ore is derived by carbonate and chert leaching during weathering, with grades decreasing in depth, in the unaltered/unchanged iron formation. Microcrystalline hematite is developed in an iron formation, with detrital conglomeratic ore generated from the base erosion of overlaid ore (Beukes et al., 2002). This mineralization process is suggested by Dardenne \& Schobbenhaus (2001) and Tolbert et al. (1971).

Hydrothermal deposits, in turn, are commonly associated with extensional faults that intersect carbon shales that form the base of the host iron formation. The mineralization is attributed to silica and carbonate leaching, and oxidation of all the iron 
to hematite. An oxidation halo commonly involves the ore bodies (Beukes et al., 2002). This action of hydrothermal fluids responsible for the iron mineralization in Carajás is supported by Dalstra \& Guedes (2004), Rosière et al. (2004, 2005), Lobato et al. (2005a, 2005b). To Rosière et al. (2004, 2005), there is still a structural control in such mineralization, since large bodies developed in zones of greater permeability, i.e., in the hinge region of the Carajás synform.

The ore hydrothermal alteration and supergene enrichment model (Beisiegel et al.,1973; Beukes et al., 2002), is characterized by the abundance of friable hematite ore in deep lateritic weathering profiles. This type of deposit, which ranges between 100 and 500 meters deep, is composed of hematite, specularite and martite. Tabular bodies of compact hematite occur associated with friable ore and predominate in the lower portion of the iron formation, while smaller lenticular ore bodies are located at the top of the succession.

\section{MATERIALS AND METHODS}

Magnetic and radiometric airborne surveys were conducted for exploration purposes at N4WS body. The airborne magnetic and gamma-ray surveys included coverage of high-density magnetic and gamma-spectrometric profiles over the study area. The magnetic survey was completed using $150 \mathrm{~m}$ flight line spacing at 100 m elevation (drape survey) with flight line directions of N25W. The magnetic survey was completed using an optically pumped (cesium vapor) magnetometer with a Scintrex CS-3 sensor at resolution of $0.001 \mathrm{nT}$ with a detection range of 20,000-95,000 nT.

The airborne gamma-ray spectrometry survey was completed using $250 \mathrm{~m}$ flight line spacing at $100 \mathrm{~m}$ elevation (drape survey) with flight line orientations of N15E for the production lines and N75W for the control lines. The gamma-ray spectrometry survey was completed using a detecting system which consisted of two downward looking groups of crystals (thallium-doped Nal) of 1024 cubic inches each, and two upward looking crystals of 256 cubic inches each.

The fieldwork in N4WS was conducted in August 2012 and May 2013 in order to document the relevant geological features of the major host rock units, the styles of mineralization in the 11 drill holes, and to sample every two meters for further petrophysical analysis. The location of the drill holes is shown in Figures 1 and 3 .

A GDD MPP-EM2S+ Multi Parameter Probe was used to measure the magnetic susceptibility and conductivity down the
11 drill holes within the N4WS prospect. The samples represent approximately $3300 \mathrm{~m}$ drilled, involving iron ore, proto-ore, jaspilite, and interlayered mafic rocks. Three measurements were taken at each point and an average magnetic susceptibility for each sample was calculated. None of the samples were found to be conductive using the multi parameter probe, therefore no conductivity measurements are reported in this study. The instrument consists of a gun-shaped probe connected to a reading unit (Palm Top) which enables the determination of the magnetic susceptibility $(x$ $\left.10^{-3} \mathrm{SI}\right)$ and relative and absolute conductivity values (mhos $/ \mathrm{m}$ ) in samples. The parameters of the equipment indicate a sampling rate 10 times per second and a presented rate every 0.5 second. Each sample consisted of three sequential measurements with a stabilization period of approximately 15 seconds.

A Radiation Solutions RS-230 BGO Super-Spec gamma-ray spectrometer was used in the laboratory inside a designed lead box to complete $\mathrm{K}, \mathrm{U}$, Th and total count assays of the $3300 \mathrm{~m}$ drilled, involving the mentioned iron ore, its proto-ore, jaspilite, and interlayered mafics.

The following auxiliary data sources were used: geological maps, data from diverse drilling campaigns, and airborne Laser Imaging Detection and Ranging survey (LIDAR) which was used to make the digital elevation model (DEM).

The software used in the processing, analysis and interpretation of the different data, were RSAnalyst, from Georadis (version 0.141.0), Oasis Montaj (version 8.2) with the Target extension, from Geosoft Inc. and ArcGIS (version 10.1) from Esri, Inc.

\section{Airborne Geophysics Data Processing}

The magnetic data were interpolated in a regular grid with $35 \mathrm{~m}$ cells using the appropriate algorithms to maintain data fidelity at the original sample locations using Oasis Montaj software, version 8.2 from GEOSOFT ${ }^{\mathrm{TM}}$. The algorithm was based on a linear interpolation along the direction of the flight lines, and on an Akima spline perpendicular to the flight lines. The analysis of the variation of the anomalous magnetic field was aided by its linear transformations, mainly the analytic signal amplitude, which is widely used to locate the spatial distribution of magnetic sources in low latitudes. The use of the derivatives, especially the first vertical derivate, helped to determine the spatial positions of the magnetic sources, and was also extremely useful to characterize linear features. The horizontal derivatives further allowed the mapping of the lateral limits of these same sources. All of these steps were guided by the analysis of the radial power spectrum of the anomalous magnetic field. 
The gamma-spectrometric data (channels TC, K, U, and Th) were interpolated in a regular grid with $60 \mathrm{~m}$ cells using the appropriate algorithms to maintain data fidelity at the original sample locations using the Oasis Montaj software, version 8.2 from GEOSOFT ${ }^{\mathrm{TM}}$. The methodology used in the interpretation of the gamma-spectrometric data involved: a) comparison of each micro-levelled grid with digital terrain data, verifying zones where the topography influenced the gamma-spectrometry response; b) analysis of the total count channel and other individual channels to define major gamma-spectrometric domains; $\mathrm{C}) \mathrm{K}$, Th, and $\mathrm{U}$ channels were displayed as RGB and CMY false-color maps (ternary images), optionally merged with digital terrain data; and d) computation of $\mathrm{U} / \mathrm{Th}$, Th/K, and $\mathrm{U} / \mathrm{K}$ ratios and analysis of their correlation with the gamma-spectrometric domains.

\section{Physical Properties of the N4WS Deposit Host Rocks, Proto-ore and Iron Ore}

As mentioned before, the data were collected to characterize the magnetic susceptibility and radiometric physical properties of the N4WS rocks. Data were obtained from the measurement of gamma radiation, including the total count channels and radioelements $\mathrm{K}$, $\mathrm{eU}$ and eTh, and magnetic susceptibility in drill cores, at 2 meters regular spacing, of a total of 1700 samples of different lithotypes.

The magnetic susceptibility in rocks depends on the amount, grain size and the mode of distribution of magnetic minerals. Its unit of measurement is dimensionless, and in this study it is indicated as SI. The magnetic susceptibility of rocks or minerals typically range from $10^{-5}$ to $3 \mathrm{SI}$ (Heider et al. 1996). Only a few minerals have high enough magnetic susceptibility to produce detectable anomalies in prospecting work. They are: magnetite, pyrrhotite (monoclinic), ilmenite, franklinite and maghemite. Due to their abundance, the first three are the main contributors to the magnetization of rocks (Gouvea \& Silva, 1995). Clark (1997) presents a summary of observation intervals and magnetic susceptibility ranges common to several types of rocks.

To collect the gamma-rays from radioelements $\mathrm{K}$, eTh and eU, a 1024 channels portable gamma spectrometer, model RS-230, manufactured by Radiation Solutions Inc., was used. It consists of a spectrometer and a cannon with a bismuth germanate used for the measurements. The equipment allows measurements of gamma radiation not only $\mathrm{K} \%$ and eU and eTh ppm but also in scintillations per minute (cpm). Samples were submitted to 5 minutes exposure to the equipment. According to IAEA (2003), the sampling time needed for a measurement depends on the radioactivity of the source and the required accuracy. For Lovborg
\& Mose (1987), 2 minutes sampling time for highly radioactive rocks and 6 minutes for low radioactivity rocks are considered acceptable according to tests using a detector with $350 \mathrm{~cm}^{3}$ of $\mathrm{Nal}$ (TI) with $10 \%$ precision. As the rocks of this study have a low radiometric response every 5 minute measurements were made. To control and eliminate external sources of radiation, an insulating box built mostly by non-radiogenic lead, was developed at the Institute of Geosciences, Universidade de Brasília.

\section{STUDY AREA CHARACTERIZATION Geological Units}

A geological map (Fig. 2), provided by Vale S.A., was used to assist in data interpretation. This map was focused in the high plateaus where the iron formation occurs. The data are a result of the final research report from Resende and Barbosa (1972), having the updating work of Macambira (2003) with focus in the iron formations and respective adjacent rocks.

The lithotypes mapped in the surveys as well as field work are arranged in a summary below, with abbreviations and adequate descriptions according to Assis (2013) and the Vale S.A. database. This designation was used in the present work to avoid the repetition of the lithological varieties throughout the text. Figure 3 illustrates the respective lithotypes.

- Ore Canga (CM): lateritic cover that forms in situ on the ore outcrops. The thickness can reach more than $20 \mathrm{~m}$. It has high Fe content and relatively low contaminants, enabling its potential use as ore. It is an indicator of the occurrence of iron ore.

- Chemical Canga (CQ): Also known as sterile lateritic cover is derived from the regolith of mafic rocks or associated with mature and cemented colluvial deposits.

- Jaspilite (JP): banded iron formation, may have centimetric to millimetric laminations often with anastomosing pattern. Laminations often appear with alternating mafic and jasper/chert. Breccias also occur with fragments of jasper enclosed in magnetite-rich matrix. Venulations commonly occur with quartz and/or carbonate. Constant variation in size between crystals of magnetite/martite. Jaspilite represents the proto-ore in the region, 20 to $40 \%$ Fe grade values.

- Friable Hematite (HF): Iron ore with an average grade of $66 \%$ Fe. Highly friable and porous structure of jaspilite, partially to totally obliterated due to silica leaching. Color 


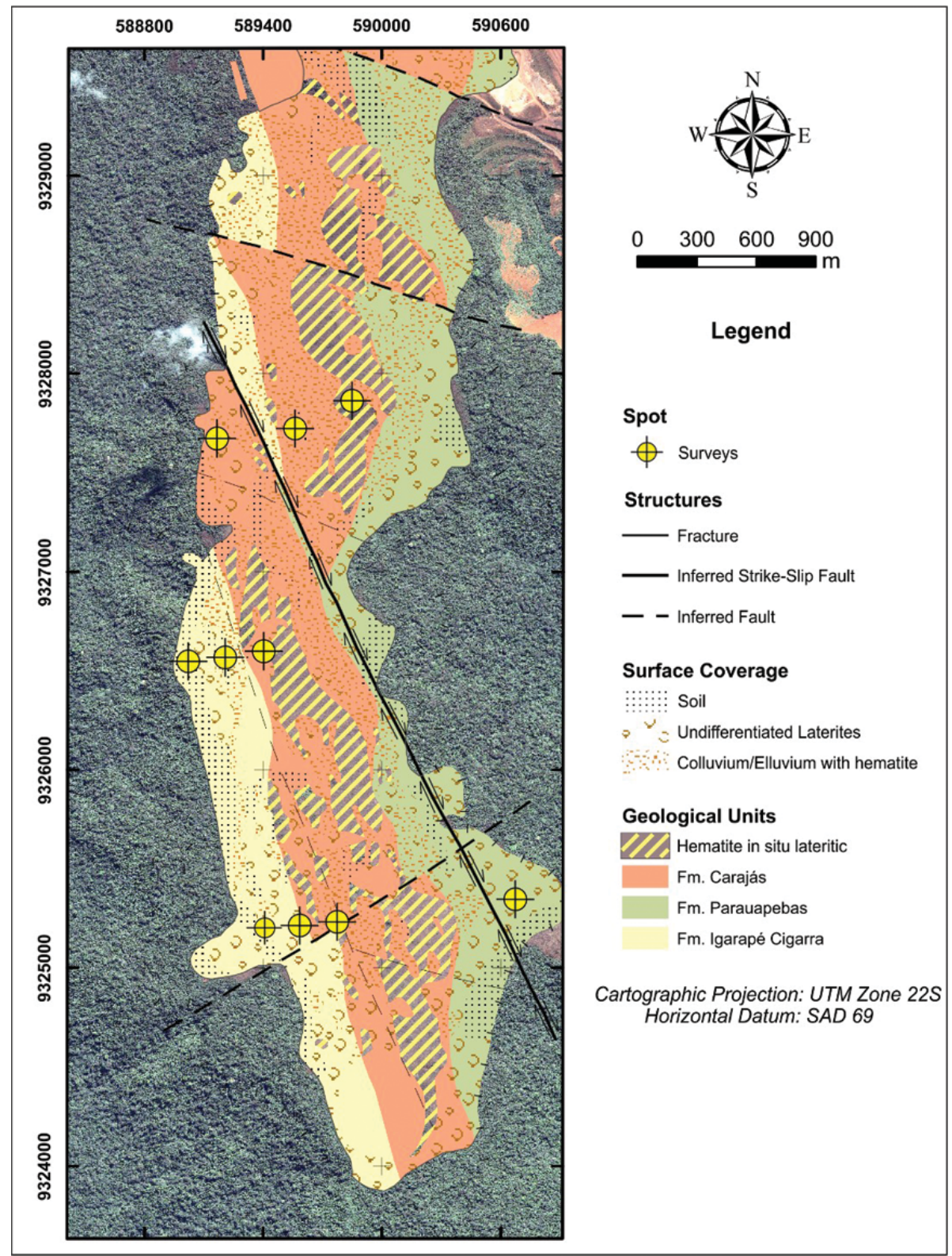

Figure 2 - Geological map of the N4WS body, focusing on lithotypes described in the plateaus of the Serra Norte. Background Image: orbital sensor Ikonos, 2007.

varies between shades of gray, sometimes yellowish associated with aluminum contamination.

- Mafic (M): basalts, gabbros and diabases little to not affected by weathering. Tuffs, pyroclastics are also described but they are rarer. They are chloritized systematically, with rich and restricted levels of talc. Mafic rocks are green to dark green, often with typical volcanic structures such as amygdale filled by quartz, carbonates and chlorites and eventually by sulfides. They occur as both flow and intrusion into the jaspilites under the form of sill.
- Semi-weathered Mafic (MS): saprolite of mafic rocks, with relicts of the original texture of the protolith or even total loss of the original structure.

\section{Magnetometry}

The anomalous magnetic field observation is enhanced by its linear transformations, mainly: the analytic signal amplitude, indicating the position of the magnetic sources; total horizontal gradient amplitude and first vertical derivative. The use of derivatives was useful in the delineation of local structures, mainly vertical. 


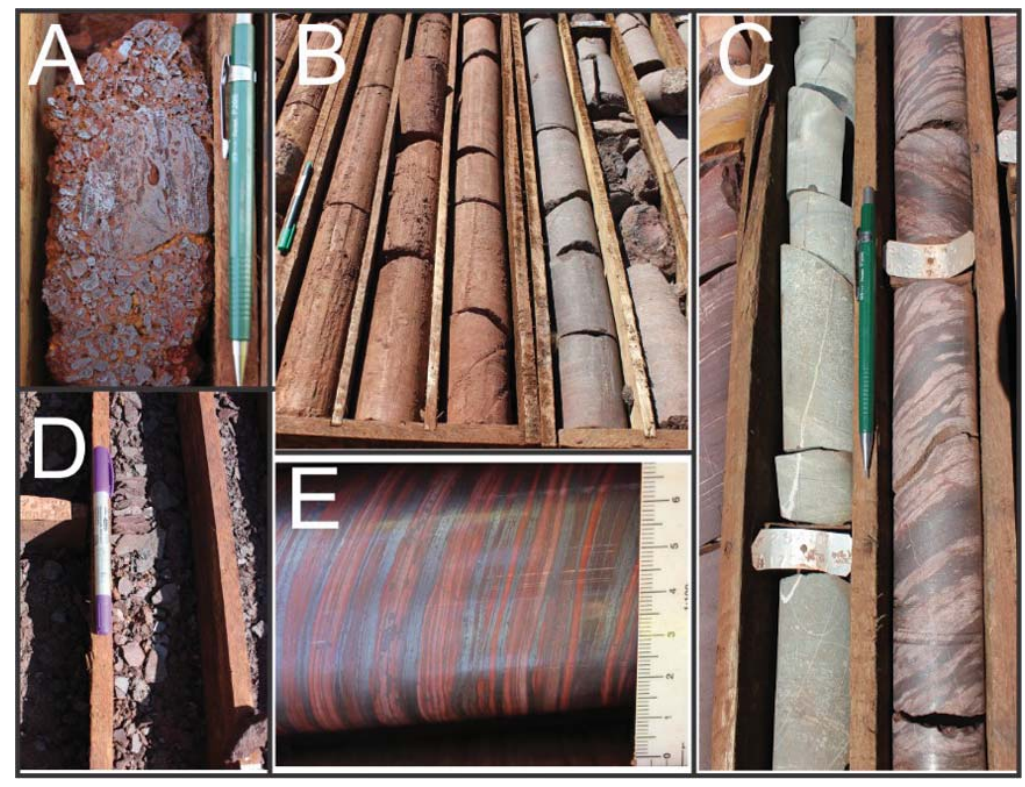

Figure 3 - Main lithotypes of the project area. A) Ore Canga. B) Chemical Canga varying to semiweathered Mafic. C) On the left Mafic rock and on the right jaspilite. D) Detail of iron ore, named Friable Hematite. E) Detail of jaspilite with jasper and iron oxides banding.

It is important to understand the relative spatial positions of the sources.

The analytical signal amplitude map (Fig. 4) shows the magnetic features and interesting structures from a prospective view. It is noted that the mineralized bodies, validated with the geological map generated from drill holes, with a high Fe content have a low gradient and are often not mapped. The main reason is the genesis of the ore, which is rich in hematite and martite (magnetite alteration) but poor in magnetite. The loss of magnetism due to the oxidation and enrichment of iron ore (Macambira, 2003) shows that the observed features are indicative of proto-ore.

\section{Gamma-ray spectrometry}

For gamma-spectrometric data, images were generated from the corrected total count data $(\mu \mathrm{R} / \mathrm{h})$ and from the channels $\mathrm{K}(\%)$, $\mathrm{eU}$ (ppm) and eTh (ppm). Among the three channels, we can highlight the channel of thorium as very relevant. Thorium is characterized by being the most inert element of the three measured ones. It has a higher concentration than the others, which may indicate regions of higher chemical weathering, typical on the study area, with thick regoliths.

Normally, in prospecting for iron ore, the gamma spectrometry data are more often used for mapping geological units associated with iron formations than for the determination of their occurrence (Flis, 2008). This is due to the low natural concentra- tion of radioelements in iron formations. In Brazil, the low values of radioelements tend to stand out as well as the association with the lateritic plateaus.

The composition in false RGB color was also quite well analyzed, and defined the gamma spectrometry signature of the regional geology of the study area. The signature of regolith associated with this unit shows plateaus enriched in eTh. However, the lateritic coverage associated with mafic rocks, associated with the Paraupebas and Igarapé Cigarra formations, is enriched eTh and eU. Clastic sedimentary rocks such as sandstones and conglomerates with arcosean matrix covering the Grão Pará group, are mapped with high $\mathrm{K}$ and were correlated with the units of Gorotire and Águas Claras Formations. It is also noteworthy a NE-SW trend with high values of $\mathrm{K}$ coinciding with the direction of the hinge zone of the anticline that separates N4 and N5. This is possibly correlated with the hydrothermal influence described in the literature (Fig. 5).

The outcropping iron formation associated with the Carajás Formation was individualized by its signature of low radioelement levels of $\mathrm{K}, \mathrm{eTh}$ and eU that show a high correlation with previously mapped outcrops (Fig. 5).

However, a more detailed characterization of the regional geology was unsuccessful, because the signal to noise ratio was relatively low, which did not allow the construction of a lithogeophysical map of Serra Norte. 


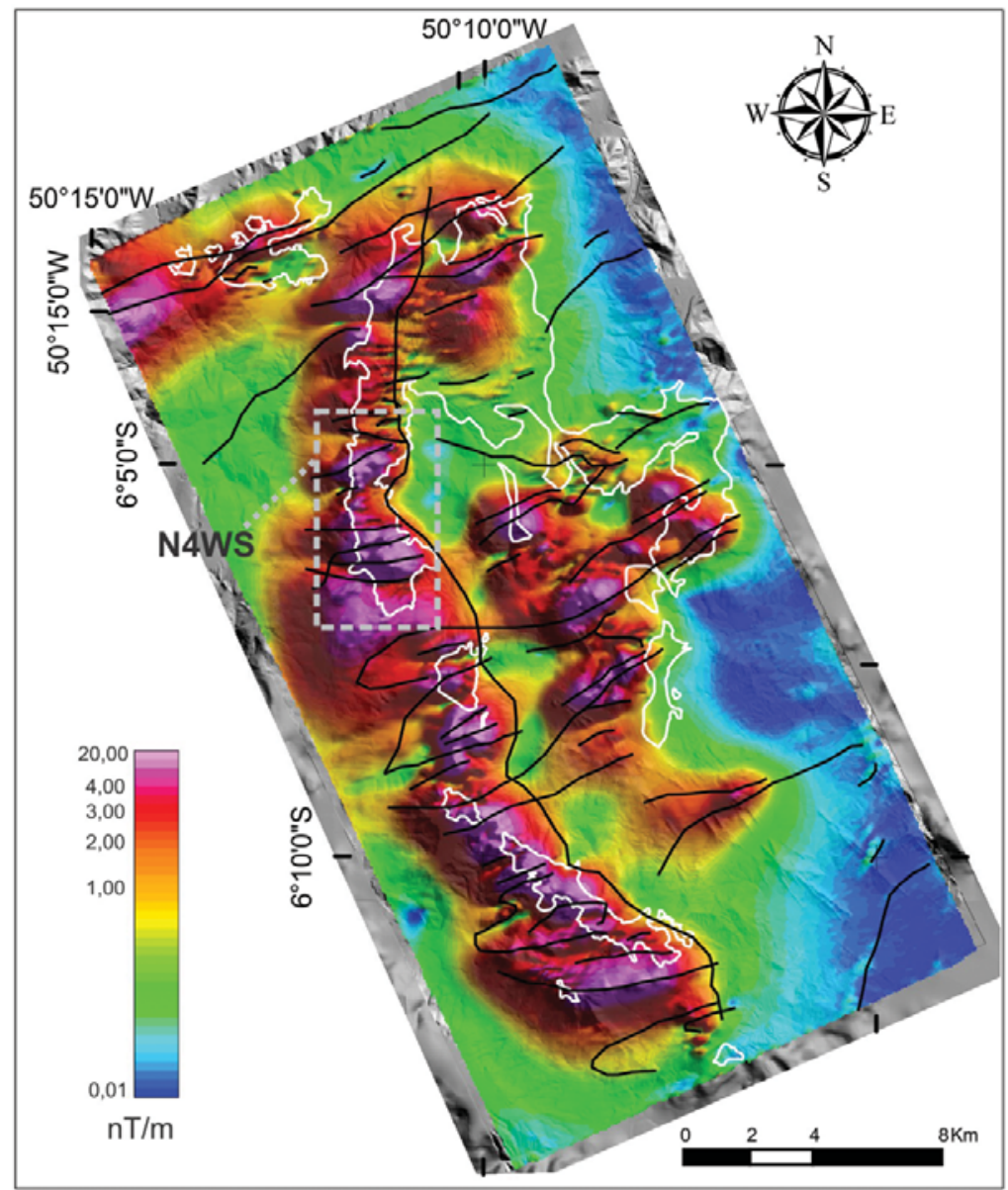

Figure 4 - Analytic Signal Amplitude map with an emphasis on digital elevation model and lineaments traced through derived anomalous magnetic field. Observe that high responses are not always coincident with the Fe mineralized bodies.

For the N4WS body a lithogeophysical map was prepared through non-supervised classification in order to check whether an individualization of the local lithotypes is possible (Fig. 6). The classification was performed for ten classes, a number considered suitable to generate the map, since a lower number does not match the observed variation and a larger number would bring unnecessary complexity to the observation of natural features in the ore body.

\section{Physical Properties of Iron Ore and Host Rocks}

The characterization of iron formations and iron ore using geophysical methods to define their physical properties is still very limited in the world, especially in Brazil (e.g. Zacchi, 2010). Some classical works determine ranges of concentration of radioelements. Killeen (1979) classifies chemical sedimentary rocks, indirectly applicable to banded iron formations, with intervals of $\mathrm{K}, \mathrm{eU}$ and eTh, respectively, between $0.02-8.4 \%, 0.03-26.7 \mathrm{ppm}$ and 0.03-132.0 ppm. Boyle (1982) presents average contents of $\mathrm{eU}$ and $\mathrm{eTh}$ for banded iron formations (2.0 ppm and $3.0 \mathrm{ppm}$ respectively). A compilation of data indicates, in summary, ranges of magnetic susceptibility for different types of iron ore and their associated iron formations, studied in Middleback Ranges, Australia and the Serra do Sapo, Brazil, respectively (Bubner et al., 2003; Zacchi, 2010) (Table 1).

A total of 1791 samples were measured, which generated a database with measurements of magnetic susceptibility and gamma radiation in the $\mathrm{K}, \mathrm{U}$ and Th channels and total count radioelements. The samples include both iron ore and the surrounding rocks described above. Sampling was performed in 11 holes spaced in 3 sections in the N4WS body (Fig. 7).

The data are presented as histograms and box plots for a better visualization of statistical data in order to facilitate their discussion. It was possible to make a classification according to lithotype (Fig. 8). 


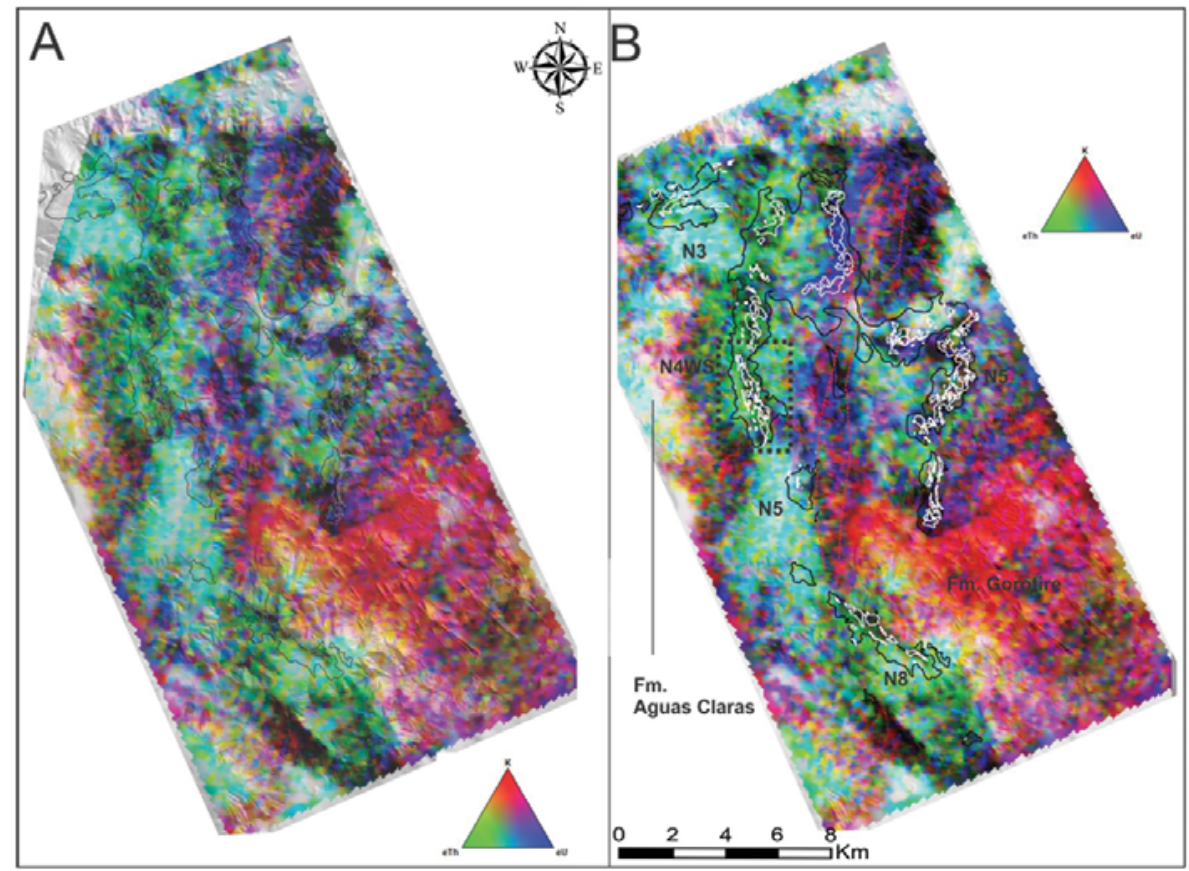

Figure $\mathbf{5}$ - RGB Colored composition of radioelements K, eTh and eU highlighted over the DEM. A) Delimitation of main geological units of the area and identification of a possible fluid percolation zone (red traced line); B) Correlation between the outcropping iron formation (white polygons) and $\mathrm{K}$, eTh and eU low grade.

Table 1 - Physical properties of iron formation in Middleback Ranges, Australia and Serra do Sapo, Brazil (Bubner et al., 2003; Zacchi, 2010).

\begin{tabular}{|c|c|c|}
\hline Lithology & Range $\times 10^{-3} \mathrm{SI}$ & Occurrence \\
\hline Iron Formation with Magnetite & 1634 & Middleback Ranges \\
Itabirite & $0.3-10.40$ & Serra do Sapo \\
Jaspilite & $17.6-2111$ & Middleback Ranges \\
Hematitic Jaspilite & $6.3-12.6$ & Middleback Ranges \\
Iron ore & $0.2-42.10$ & Serra do Sapo \\
Iron ore (rich magnetite) & $4.4-2111$ & Iron Duke \\
Hematitic iron ore I & $30.2-52.8$ & Middleback Ranges \\
Hematitic iron ore II & $1.0-10.0$ & Middleback Ranges \\
Hematitic Quartzite & $1.63-1684$ & Middleback Ranges \\
\hline
\end{tabular}

The magnetic susceptibility values show a wide variation in the range examined, from samples with zero values up to the maximum of $935.33 \times 10^{-3} \mathrm{SI}$, with an average of $49.02 \times 10^{-3} \mathrm{SI}$. The jaspilite and friable hematite show high values of susceptibility when compared to the surrounding rocks, but proto-ore has much higher values than the ore itself, with averages of 234.37 $\times 10^{-3} \mathrm{SI}$ and $26.17 \times 10^{-3} \mathrm{SI}$, respectively. Mafic rocks, along with their saprolitizated product have low magnetic susceptibility, especially semi-weathered mafic rocks with average value of 0.39 $\times 10^{-3} \mathrm{SI}$. The mafic rock has an average of $3.11 \times 10^{-3} \mathrm{SI}$. Cangas derived from both jaspilitos, ore canga, and the mafic rocks, chemical canga, also have low values of magnetic susceptibility, with averages of $6.13 \times 10^{-3} \mathrm{SI}$ and $0.52 \times 10^{-3} \mathrm{SI}$, respectively.

Differentiation through the average values of the magnetic susceptibility is efficient. However, due to local geological features, such as level of strong weathering caused by the tropical climate and the typical local characteristics, there is a large number variation within the lithotypes. For jaspilites, this variance is 


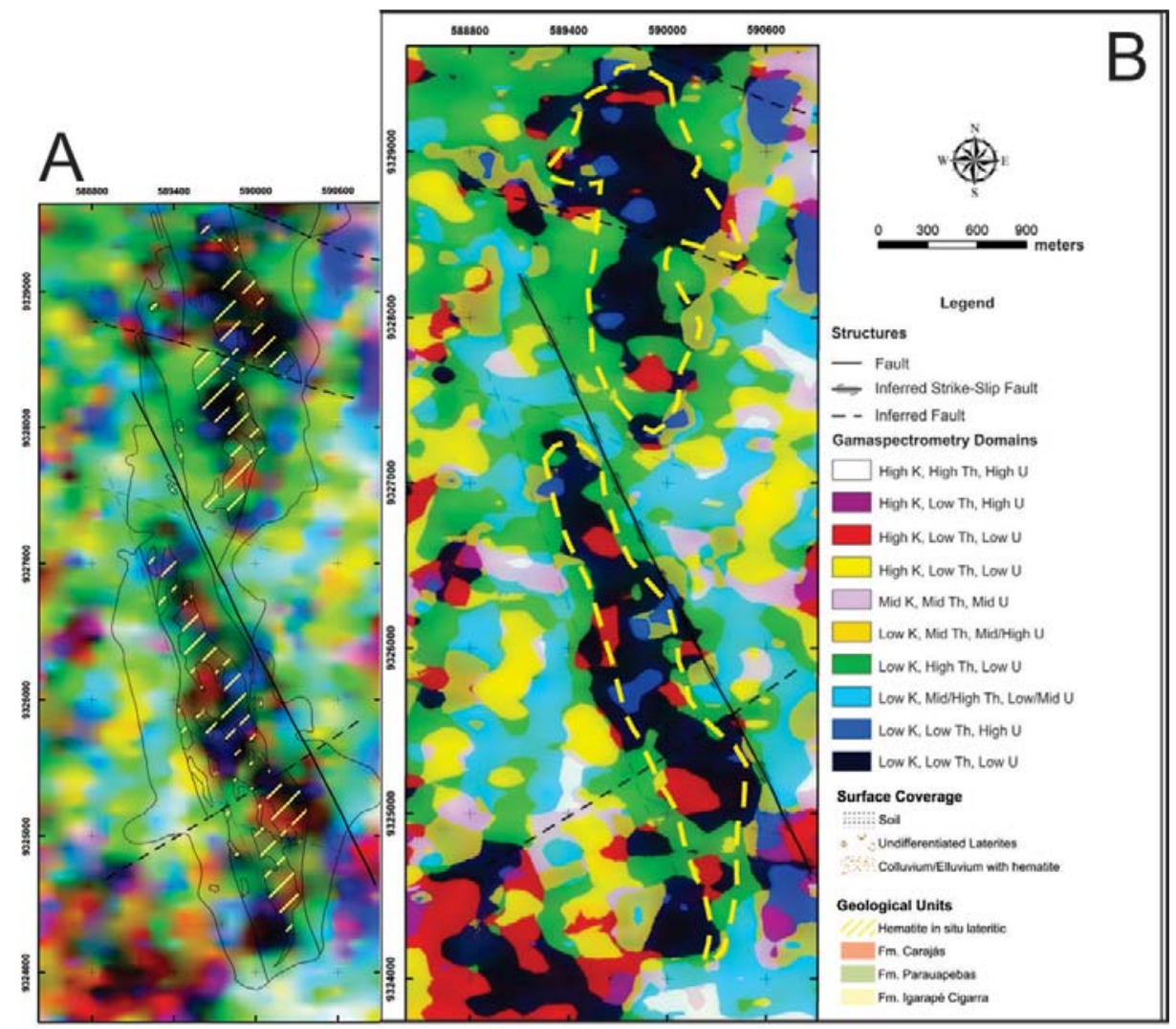

Figure 6 - A) RGB ternary composition (K/eU/eTh) with geological contacts in evidence; B) N4WS Lithogeophysical Map. Note the regions delineated coincident with indicative iron ore outcrops.

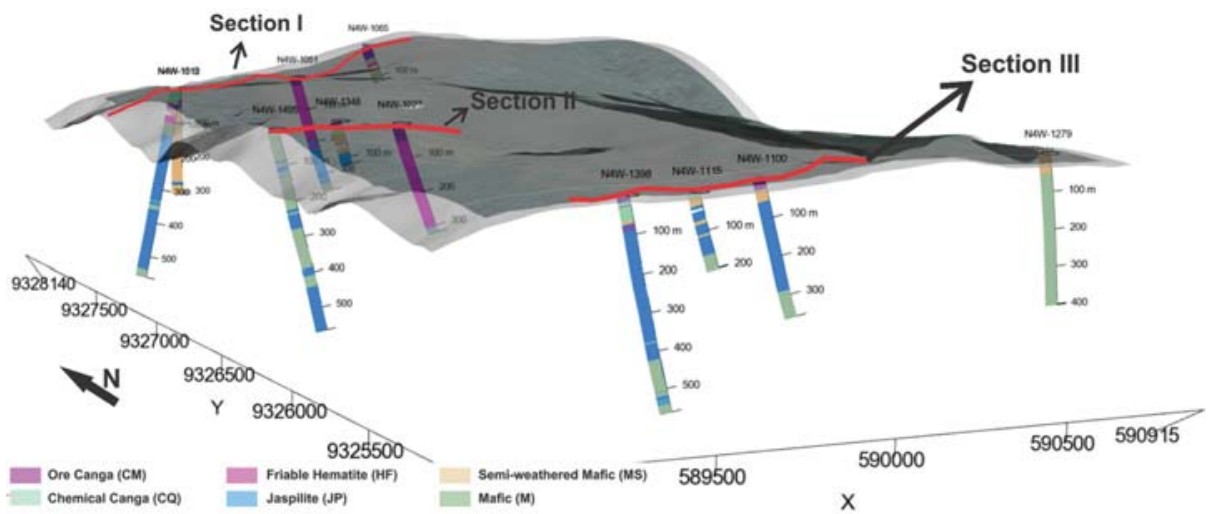

Figure 7 - Location of the drill holes in N4WS body. The highlighted sections were used to help data interpretation.

between $0.51-904.33 \times 10^{-3} \mathrm{SI}$, where lower values are relative to the partially modified portions, connected to the oxidation of magnetite, and also associated to the interaction with mafic bodies (sills) in the package. The same kind of criteria can be applied to the canga ore and mineralized portion. The first has variation between $0.31-25.17 \times 10^{-3} \mathrm{SI}$ and the friable hematite shows values between $0.5-111.33 \times 10^{-3} \mathrm{SI}$. The canga ore is mostly poor in magnetite, consisting essentially of iron oxides and hydroxides. The ore is derived from the oxidation of magnetite to hematite. Mafic rocks, semi-weathered mafic rocks and chemical canga have the following range of values: $0-21.27 \times 10^{-3} \mathrm{SI}$, $0-1.69 \times 10^{-3} \mathrm{SI}$ and $0.14-1,24 \times 10^{-3} \mathrm{SI}$, respectively. Anomalous magnetic susceptibility values for mafic rocks are shown in Figure 9 . They are related to the proximity of the jaspilites, which 


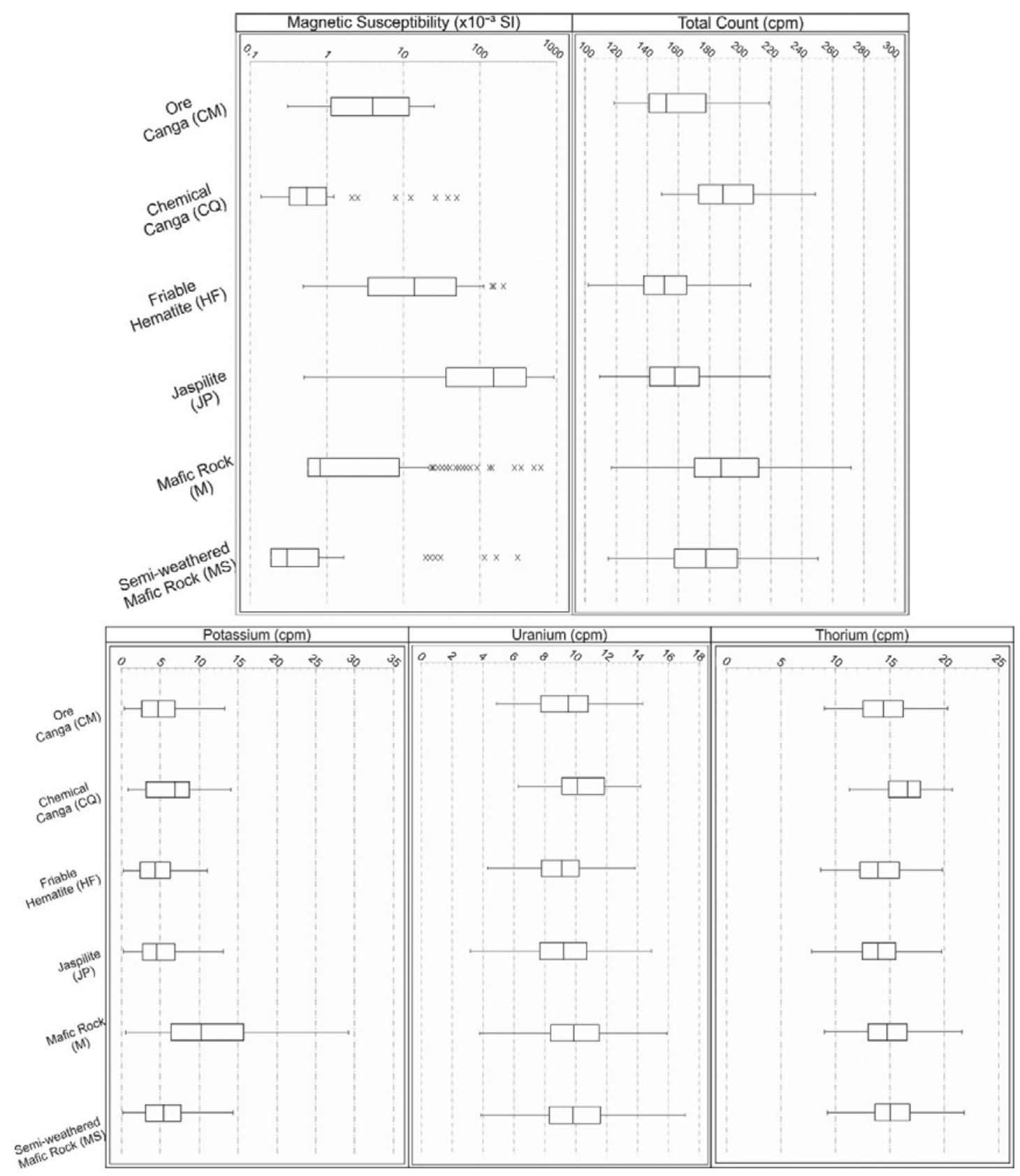

Figure 8 - Box plot showing the values of magnetic susceptibility and gamma spectrometry (total count, potassium, uranium and thorium) samples of ore and surrounding rocks.

suggests an interaction between them, as shown at some levels of jaspilites. They are cut by sills in which these fragments are presented with chert and jasper in the matrix and also by alternation of mafic and jasper centimetric bands.

The data obtained using the gamma-ray spectrometer for the lithotypes studied are summarized in Table 2, with the mean and range described. The values of the three radioelements, potassium, uranium and thorium, are arranged in cpm (counts per minute) as opposed to the commonly used concentrations (\% and ppm). The standard scale, derived from the processing of raw data is exported in concentrations, but the largest range of values in cpm was more useful for the evaluation and differentiation of the tested lithotypes.

In general, the measured values are very similar showing no remarkable difference between the ore and its surrounding rocks. High values of $\mathrm{K}$ for the mafic rocks can be highlighted, with 


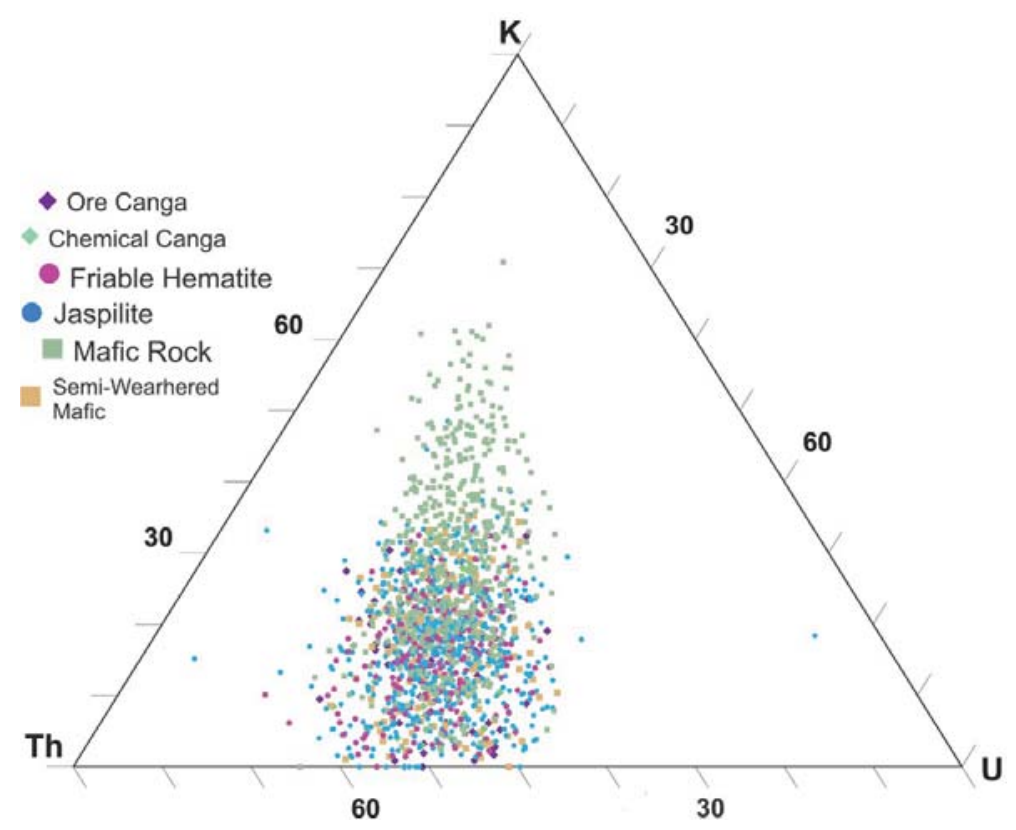

Figure 9 - Normalized K/eU/eTh ternary diagram. Data from all samples from the N4WS body.

Table 2 - Summary of mean and variation of magnetic susceptibility values, total count, potassium, uranium and thorium for the described lithotypes.

\begin{tabular}{|c|c|c|c|c|c|c|}
\hline Lithology & & $\begin{array}{c}\text { Magnetic } \\
\text { Susceptibility } \\
\left(\mathrm{SI} \times 10^{-3}\right)\end{array}$ & $\begin{array}{c}\text { Total } \\
\text { Count } \\
(\mathrm{cpm})\end{array}$ & $\begin{array}{c}\mathrm{K} \\
(\mathrm{cpm})\end{array}$ & $\begin{array}{c}\mathrm{U} \\
(\mathrm{cpm})\end{array}$ & $\begin{array}{c}\text { Th } \\
(\mathrm{cpm})\end{array}$ \\
\hline Ore & Mean & 6.15 & 160.11 & 5.11 & 9.41 & 14.47 \\
Canga (CM) & Range & $0.31-25.17$ & $118.50-218.60$ & $0.4-13.30$ & $4.90-14.30$ & $9.00-20.3$ \\
\hline Chemical & Mean & 0.52 & 191.1 & 6.47 & 10.29 & 16.33 \\
Canga (CQ) & Range & $0.14-1.24$ & $149.60-248.30$ & $0.90-14.10$ & $6.30-14.20$ & $11.30-20.70$ \\
\hline Friable & Mean & 26.17 & 149.56 & 4.45 & 9.10 & 14.02 \\
Hematite (HF) & Range & $0.50-111.33$ & $102.20-206.50$ & $0.30-11.10$ & $4.30-13.80$ & $8.70-19.80$ \\
\hline Jaspilite & Mean & 234.37 & 158.34 & 4.91 & 9.26 & 13.94 \\
(JP) & Range & $0.51-904.33$ & $109.30-219.00$ & $0.30-13.10$ & $3.20-14.90$ & $7.80-19.70$ \\
\hline Mafic Rock & Mean & 3.11 & 191.5 & 11.27 & 9.88 & 14.85 \\
(M) & Range & $0-21.27$ & $117.00-271.60$ & $0.60-29.20$ & $3.80-15.90$ & $9.00-21.60$ \\
\hline $\begin{array}{c}\text { Semi-weathered } \\
\text { Mafic (MS) }\end{array}$ & Mean & 0.39 & 179.11 & 5.5 & 9.93 & 15.17 \\
\hline
\end{tabular}

values ranging between $0.60-29.20 \mathrm{cpm}$ and $11.27 \mathrm{cpm}$ average, much higher than other lithologies. Ore and chemical cangas have higher values for thorium as compared to other rocks because of their natural enrichment derived from local weathering processes. Thorium is the focus in this process because it is the least geochemically mobile radioelement. Positive anomalies within these variables, when associated, can be interpreted as possible indicators of hydrothermal processes linked to various types of min- eralization (e.g. Pires, 1995; Airo, 2002). A ternary diagram with values of normalized potassium, uranium and thorium radioelements was used for comparing the sampled data in the N4WS body (Fig. 9). The sampled lithotypes have high dispersion, thus hindering a classification derived from the radioelements except for the mafic rocks, with a trend indicating enrichment in potassium. There is no differentiation between jaspilite and iron ore, indicating possibly that the mineralization is not directly related 
to hydrothermal events or that the chosen parameters are not applicable to the mineralization process.

The values observed in the total count channel obtained from the measurement of gamma radiation, show a better differentiation between the sampled lithotypes. It is possible to separate two general classes: jaspilites, together with the ore and the canga, and mafic rocks, with their semi-weathered portion deriving into chemical canga. The second group has higher mean values compared to the first one, while mafic rocks, semi-weathered mafic and chemical cangas have, respectively, mean cpm values of $191.50,179.11$ and $191.10 \mathrm{cpm}$. The jaspilites together with friable hematite and ore canga, have average values of 158.34 , 149.56 and $160.11 \mathrm{cpm}$, respectively. Despite the difference in values between the friable hematite and jaspilite, it is not possible to distinguish them because their ranges are virtually identical, the same being applicable to ore canga (Table 2 and Fig. 8). This behavior is compatible with the dispersion observed for potassium, uranium and thorium.

The high amount of data obtained by drilling makes a single view of each drill hole inadequate. For this reason, the drill holes are arranged in three parallel sections, called sections I, II and III. Figure 10 ( $A$ and $B$ ) shows the profiles of each drill hole with the profile of the magnetic susceptibility (pink) in logarithmic scale, and total count in linear scale. These parameters were found to be the most useful for the differentiation between the mapped lithologies. Just above the profiles, the image of the airborne survey RGB ternary composition is inserted for comparison between the position of the survey and its respective gamma-spectrometric response in surface.

In order to enhance the interpretation, correlation charts comparing all the physical parameters analyzed were generated. They allow better visualization and they are also useful in the classification of lithotypes according to their present features. Figure 11 illustrates an example of the hole F1495/N4WS with the relationship between the radiometric channels and their interaction with the magnetic susceptibility. It is noteworthy the use of normalized data for $\mathrm{K}, \mathrm{U}$ and Th channels, which depicts more accurately the interaction between these radioelements.

From this graph, it is possible to identify the difference in behavior of radioelements between mafic rocks and jaspilite (Fig. 11A, B and C). Figure 11D illustrates how the total count and the magnetic susceptibility are useful in the individualization of the sampled lithologies.

The data sections I, II and III were also analyzed through correlation graphics. The sections are presented together in Figure 12. In the potassium and uranium graphic (Fig. 12A) the data from section I show great dispersion, without any distinction between lithologies, even if some data are far from this "point cloud" which have little representation as a total. Sections II and III illustrate a small negative trend, indicating a tendency of mafic rocks to be richer in potassium and poor in uranium (most notably in section II). The other lithotypes cannot be distinguished directly, all showing low uranium response.

Figure 12B, which presents the correlation between potassium and thorium, is similar to the previous behavior chart, being observable a greater slope in the relationship between the increase in potassium and a decrease in thorium. There is no differentiation between the type of iron ore, jaspilites and cangas. Mafic rocks again stand out in their greater potassium response, but still a considerable amount of sample behaves in a similar way as other lithotypes.

The graphic of uranium and thorium correlation (Fig. 12C) depicts well the behavior of the mafic rocks of the study area. They are richer in potassium and impoverished in thorium and uranium when compared to adjacent lithologies. This differentiation is more evident in the samples from section II. Jaspilites, friable hematite, ore and chemical cangas, have similar values of normalized uranium and thorium.

When total count and magnetic susceptibility are compared (Fig. 12D), there is a clear differentiation between the main lithotypes analyzed. Both sections show that, despite showing similar values for total count, jaspilites and friable hematite are distinguishable by the parameter of magnetic susceptibility. While the values of jaspilite are predominantly above $100 \times 10^{-3} \mathrm{SI}$ (with some exceptions), friable hematite is "confined" below this value. This behavior is clearly observed in sections I and II which have a higher amount of ore samples. The mafic rocks, and their lithologies, have similar behavior for magnetic susceptibility, always restricted to the range of $10 \times 10^{-3} \mathrm{SI}$. Mafic rocks with values above this, can be considered as a product of interaction with nearby jaspilites, the most frequently observed situation in Section II. Such rocks, as expected, stand out by higher values of total count.

From the analysis and visualization of the results of the sections, an individual analysis of the drill holes becomes interesting, in order to identify possible anomalies. The F1495/N4WS drilling sampled almost the entire local stratigraphy and its rocks are the most well preserved, allowing a clearer analysis of the physical properties of these rocks. The log of this drill hole (Fig. 13) shows the three radiometric channels and the total count, their ratios and the "F factor" ('KU)/Th'). It shows possible areas of potassium enrichment derived from hydrothermalism, suggesting local enrichments, as compared to the magnetic susceptibility. 

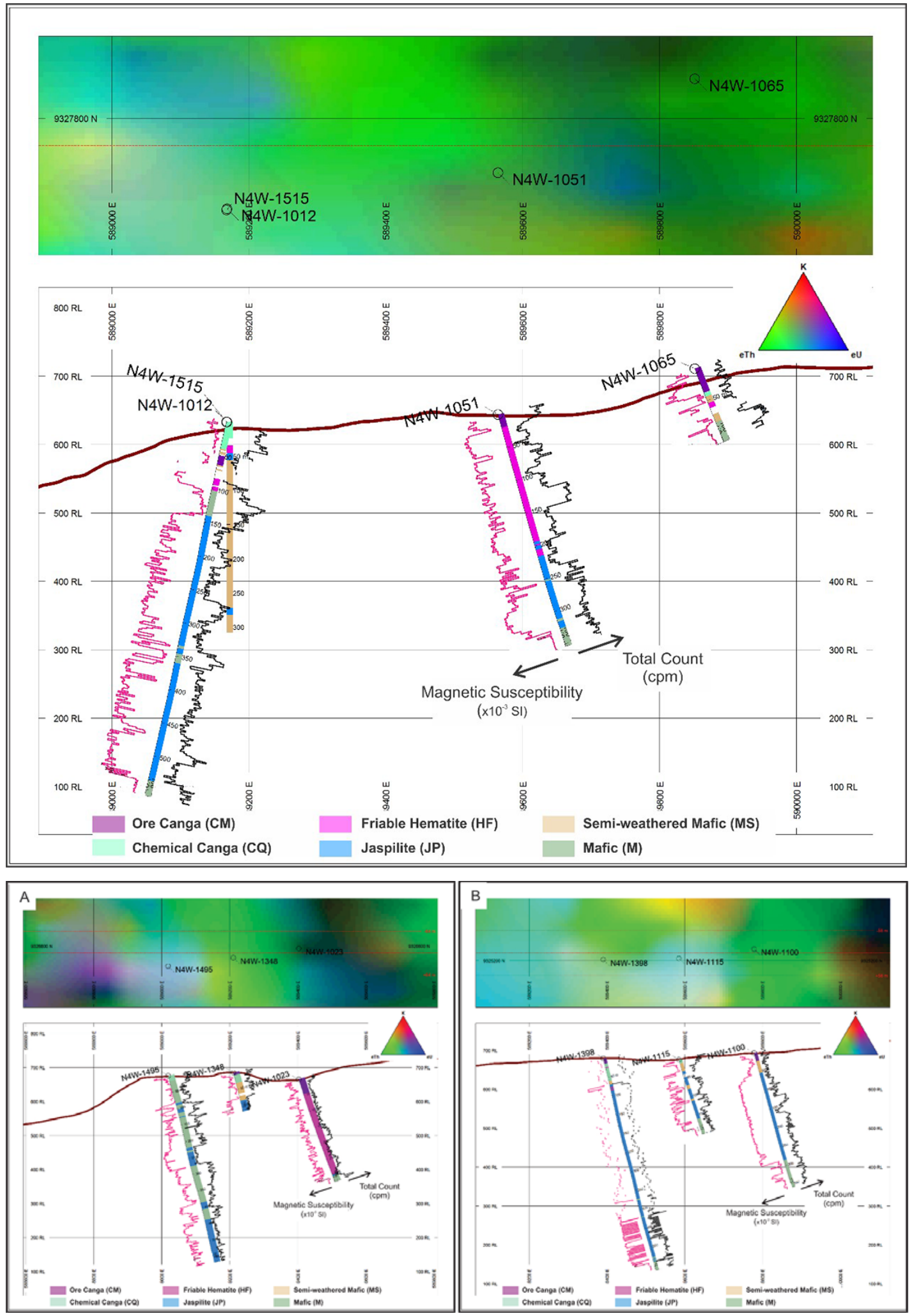

Figure 10 - Section I (top) illustrating their logs with profiles of magnetic susceptibility and total count of radioelements. RGB ternary composition (K, eU, eTh). Sections II (A) and III (B) illustrating their logs with profiles of magnetic susceptibility and total count of radioelements. RGB ternary composition (K, eU, eTh). 


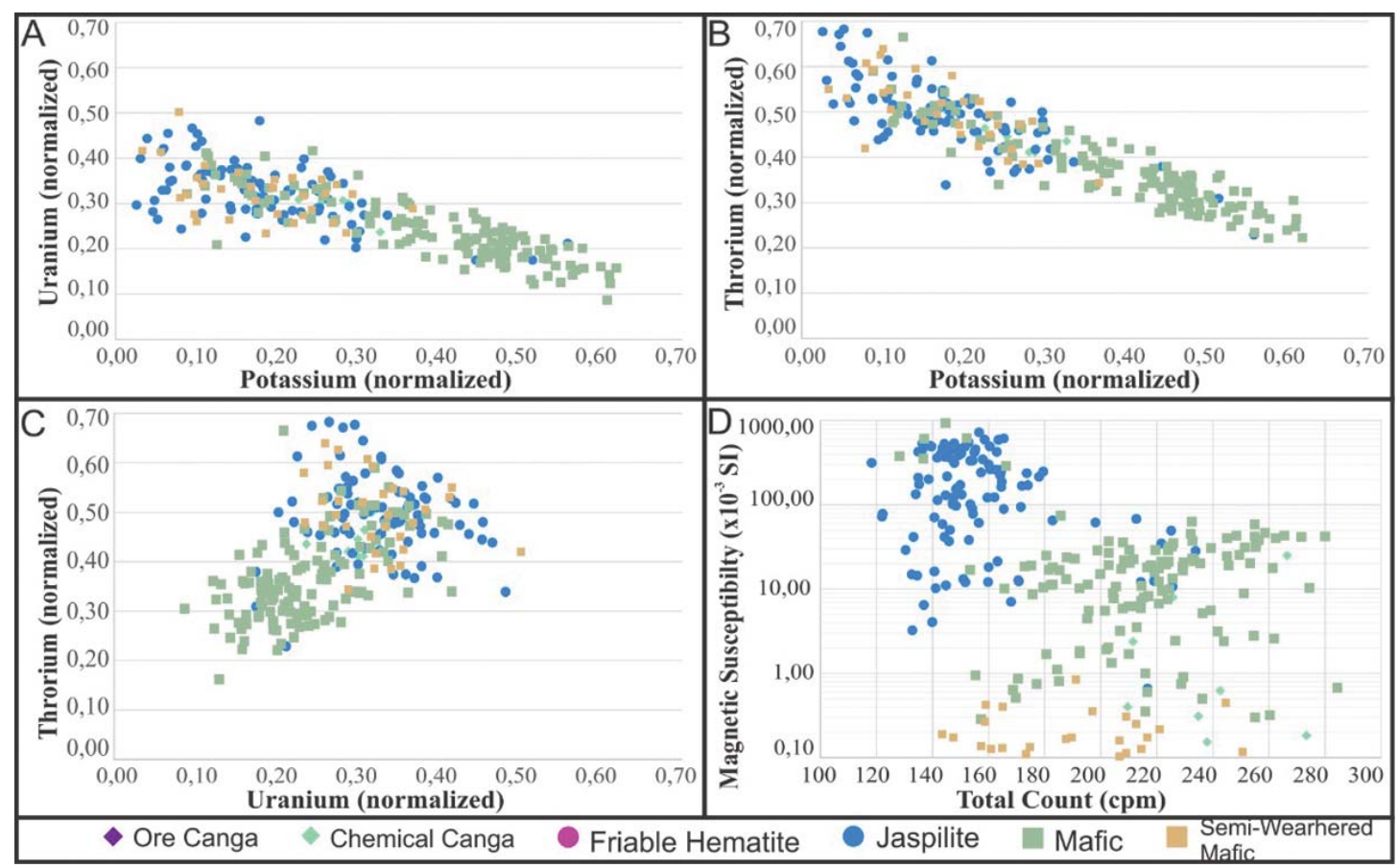

Figure 11 - Graphic of correlation F1495/N4WS hole. A) Correlation between potassium and uranium. B) Correlation between potassium and thorium. C) Correlation between uranium and thorium. D) Correlation between total count and magnetic susceptibility (logarithmic values). The values of the radioelements are normalized.

In the analysis of the log it is possible to identify variations in physical properties, more precisely the magnetic susceptibility, the total count (TC) and the potassium channel between jaspilites and the mafic rock. Such differentiation within the physical properties allows the automatic classification of the lithotypes. The geophysical data were subjected to a non-supervised classification, in which the K-means algorithm was used, which provides an image based on analyzes and comparisons between numerical values of the data itself, without any supervision or preclassification rankings. By presenting different magnitudes (cpm, $\mathrm{SI}$ ), the data were normalized only by their means and standard deviations. The high variance of the lithotypes in the drill holes prevented a standard rating for the entire N4WS body. Thus, a different determination of the number of distinct classes was used for each drill hole depending on its geological characteristics. At first, the classification appeared to be satisfactory to determine the lithotypes. Figure 14 illustrates the result of the classification compared with geological sampled data. Only the magnetic susceptibility, total counting and potassium values were used because these had the most satisfactory results.

The classification results were ambiguous. In the F1495/ N4WS log, the classification of the data separated well the jaspilites from mafic rocks. They also indicate a variation in the jaspilite itself connected to the magnetic susceptibility variation, indicating that despite the macroscopically homogeneous jaspilite, there is heterogeneity within the rock itself. Results in the semi-weathered mafic (MS) do not differ from the chemical canga (CQ) illustrating that possibly weathering processes do not affect directly the analyzed physical properties. The classification of the F1023/N4WS log was not so satisfactory for differentiating the sampled lithologies. Ore canga (CM), iron ore and friable hematite (HF) have the same answers to the classification of two classes being applied to the two lithotypes. Failure to differentiate between iron ore and canga indicates that weathering processes do not significantly alter the radioelements concentration. The same is applicable for magnetic susceptibility, low in both lithotypes, essential for non-magnetic mineral compounds like hematite (ore constituent) and goethite (canga constituent). The mafic rock (M) of the base of the hole could not be classified, perhaps because of its low representation in the survey.

In summary, the same results are obtained for the other drill holes. The non-supervised classification indicates a partitioning within the jaspilite itself and the generation of the same class for the lithotypes defined as chemical canga (CQ) and semiweathered mafic (MS); also to define the ore canga (CM) and friable hematite (HF). 


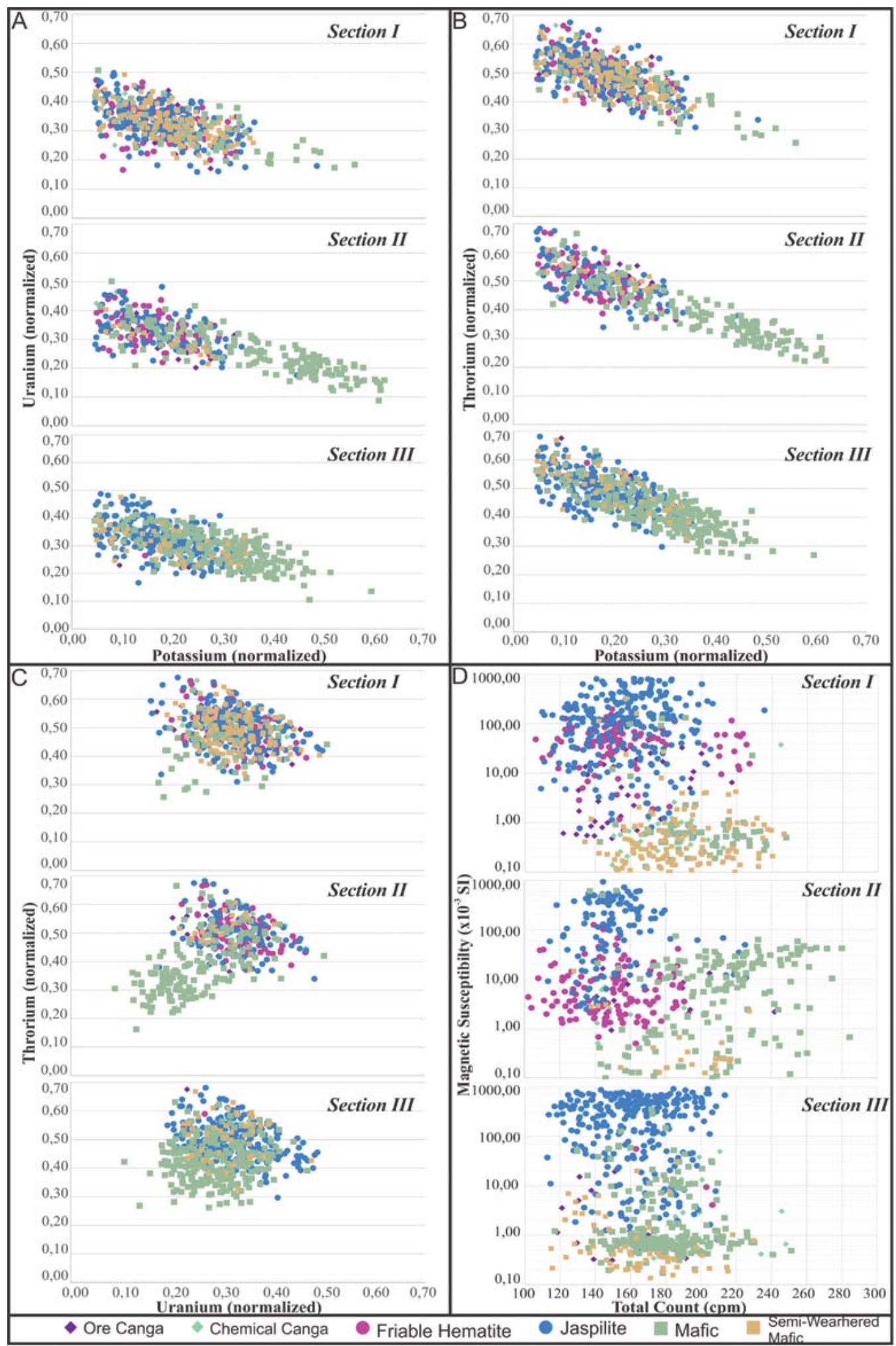

Figure 12 - The correlation charts of sections I, II and III in N4WS body. A) Correlation between potassium and uranium. B) Correlation between potassium and thorium. C) Correlation between uranium and thorium. D) Correlation between total count and magnetic susceptibility (logarithmic values). The values of the radioelements are normalized. 


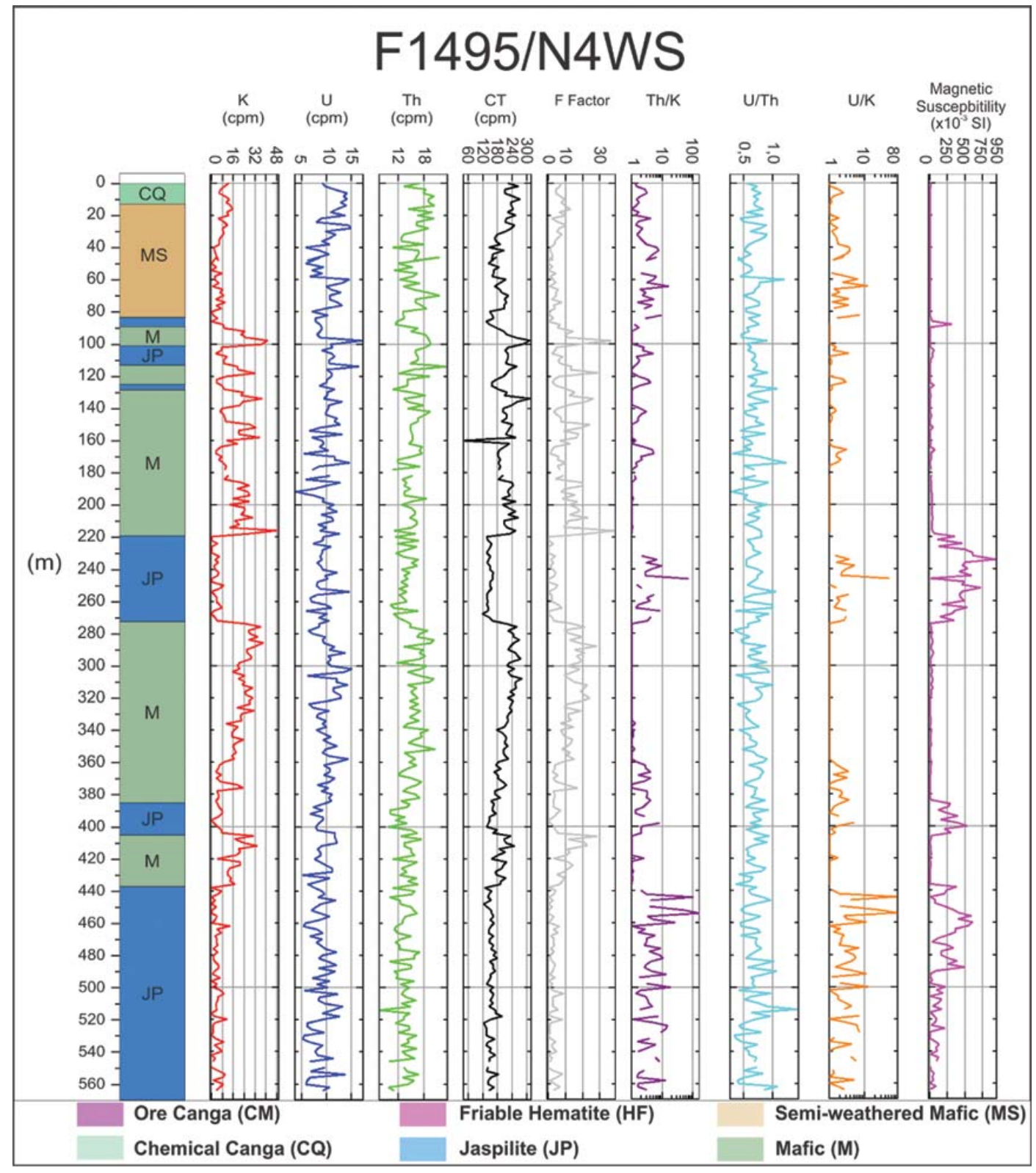

Figure 13 - F1495/N4WS drill hole log with the response profiles of the radioelements, their ratios and the magnetic susceptibility.

\section{Integration of rock physical properties, Geology and Airborne Geophysical Data}

The analysis of data sampled at different scales through individual drill hole logs and from the correlation charts of the entire population of measurements allowed a higher understanding of the behavior of the physical properties of the N4WS body. It allowed a greater integration between the used tools.

First of all, it is necessary to have the knowledge of the geological sections to have an idea of the spatial variation of the physical properties measured. Vale S.A. provided the lithologi- cal information from the other drill holes presented in sections I, II and III.

Using the Target extension built for, Geosoft Oasis Montaj software, which allows the creation of interactive surfaces, named geostring's, with information derived from drilling. Platform interpretations were generated in profiles of the respective sections, taking into account the geological descriptions conducted in sampled drill holes, dip information on the layers of jaspilites and major structural features provided by Vale S.A. (Figs. 15 and 16). The sections are limited laterally by a $100 \mathrm{~m}$ buffer. Above the 


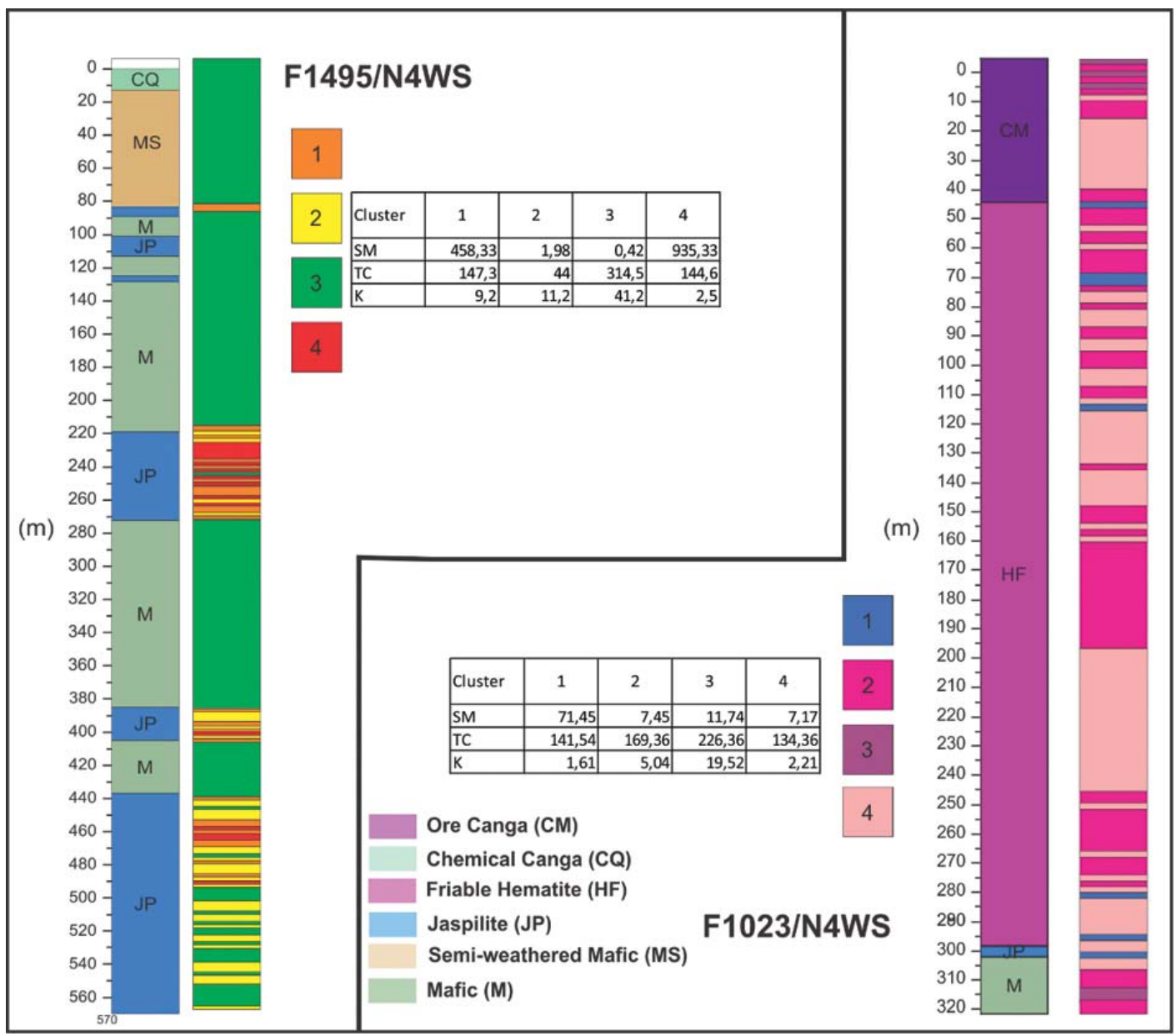

Figure 14 - Non-supervised classification of geophysical data from F1495/N4WS hole.

sections, it is presented the RGB ternary composition image from the airborne gamma-ray spectrometric survey with the position of the drill holes and the structural features mapped on surface.

Section I is cut by two normal faults, with the area of highest mineralization concentrated between them. There is clearly an indication that the "front" of weathering, which advances up to $200 \mathrm{~m}$ deep, follows the bedding, advancing in the east - west direction. Section II also features two faults that cut the profile, and similarly the mineralized zone is imposed by both, but such structures have no relation with those presented in Section I. In the upper portion, shear zone was identified and interpreted with the help of the geological descriptions of the F1495/N4WS and F1348/N4WS holes as a thrust. Again, it is important to note the observation of weathered rocks, this time at more than $250 \mathrm{~m}$ deep. The high structuring of the area indicates that the mapped structures act as surface conduits for percolation fluid, which would intensify the process of rock alteration. Section III shows less influence of the structures observed at the local level. The region of highest mineralization is concentrated to the right of normal fault mapped on surface and also cuts to Section II. There is a fault mapped to the left according to the F1115/N4WS hole description. Mineralization and weathering are concordant to I0cal bedding, naturally, due to easier percolation for fluids and rock leaching.

Interpretations of the physical properties were also generated alongside the geological profiles, not considering relevant the local geology. Thus, only the sampled drill holes were considered for fitting the profiles (Figs. 17 and 18). The magnetic susceptibility and total count profiles are presented along the drill hole profiles in order to facilitate visualization of the different responses within their lithotypes.

The k-means classification was helpful in regard to differentiation of jaspilites and weathering processes. Section I follows this proposal, defining the same zone as the chemical canga (CQ) 


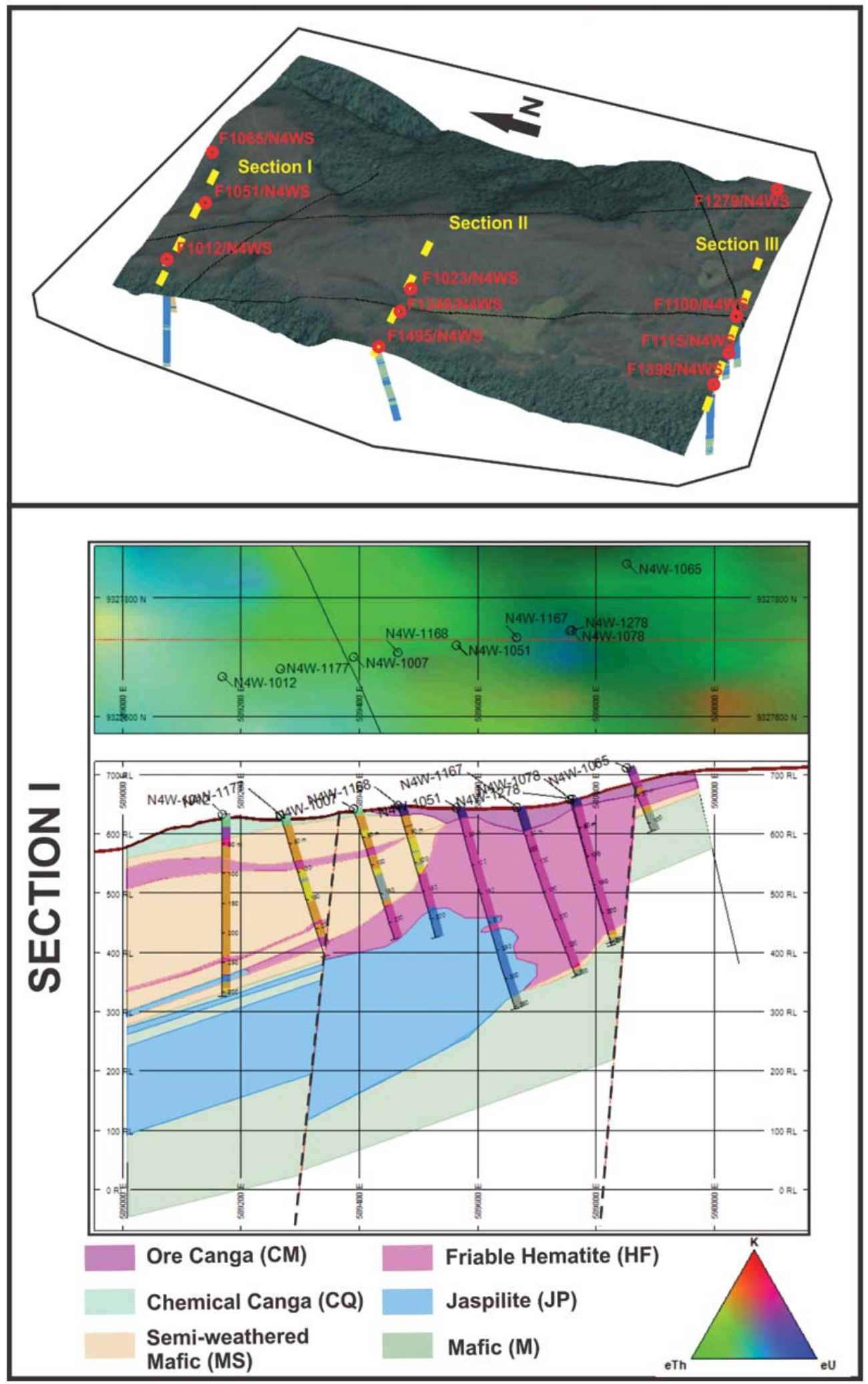

Figure 15 - Section I with geological interpretations using drilling data provided by Vale S.A; RGB ternary composition (K, eU, eTh). 


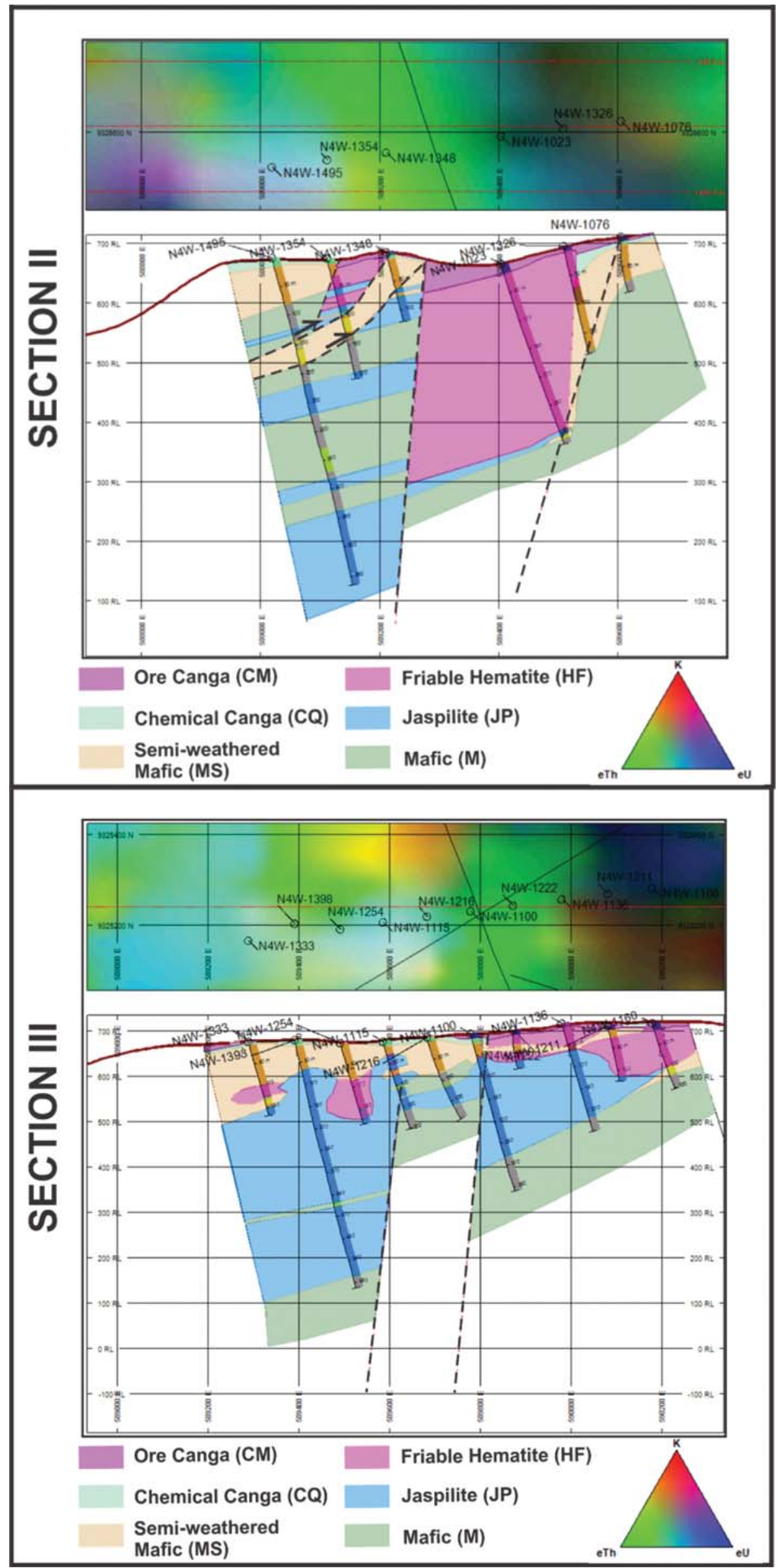

Figure 16 - Sections II and III with geological interpretations using drilling data provided by Vale S.A; RGB ternary composition (K, eU, eTh). 


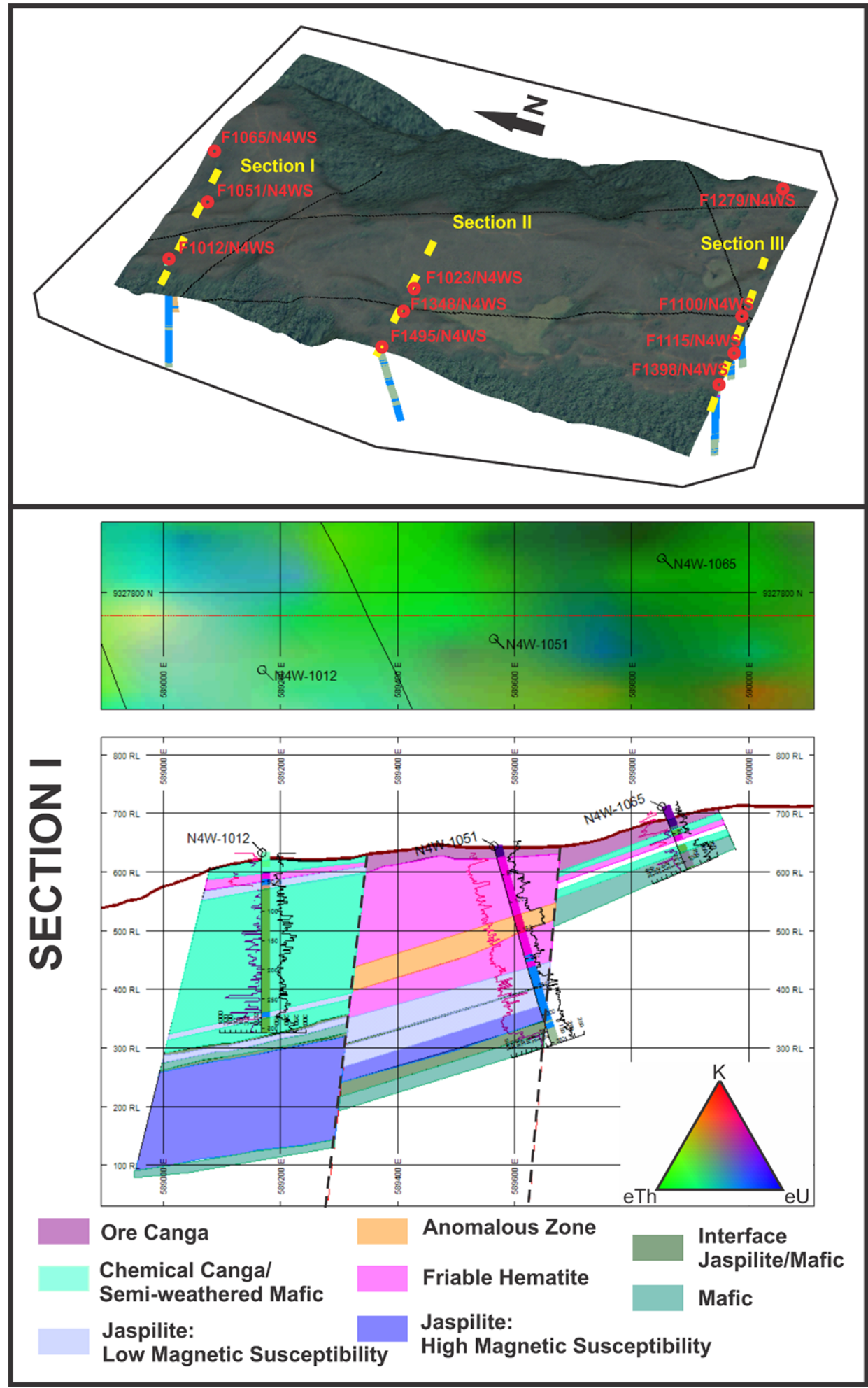

Figure 17 - Section I with the interpretations of the 'petrophysical zones' and their respective drilling; RGB (K, eU, eTh) ternary composition. 


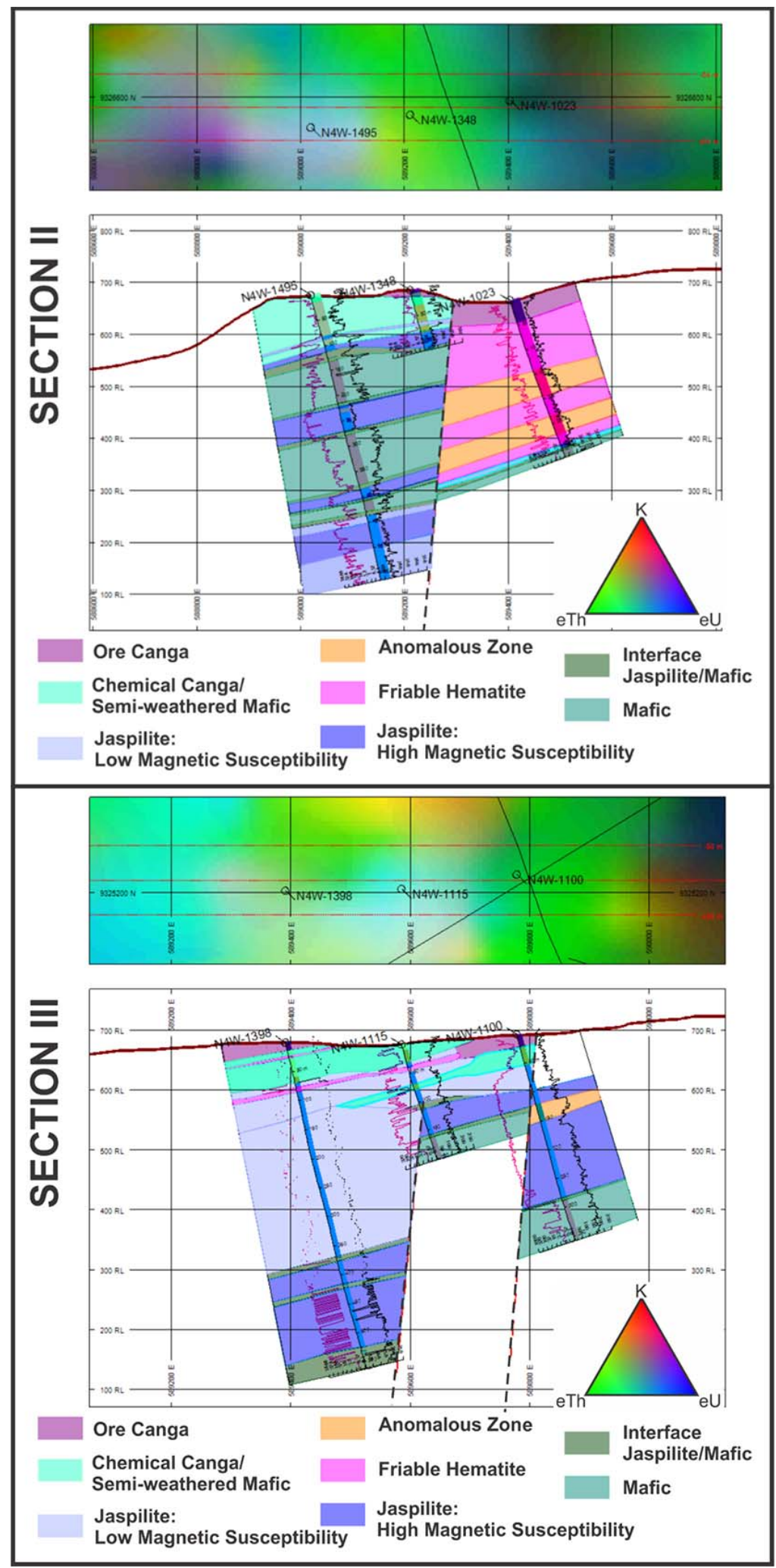

Figure 18 - Sections II and III with the interpretations of the 'petrophysical zones' and their respective drilling; RGB (K, eU, eTh) ternary composition. 
and semi-weathered mafic (MS). The jaspilites are differentiated into two types: those with low magnetic susceptibility, in the upper portion of their respective lithotype, limited to $250 \times 10^{-3} \mathrm{SI}$. However, in the second type, those with high magnetic susceptibility are apparently associated with the base of the section, with mean values higher than $250 \times 10^{-3} \mathrm{SI}$ and reaching up to 1000 $\times 10^{-3} \mathrm{SI}$. Both have radiometric behavior as evidenced by the total count profiles. There is still an area of interface to the mafic rocks located within the jaspilites package. Described as sills, they present higher magnetic susceptibility values and a slight decrease in the radioelement concentrations compared to the same rock located farther from the contact. A similar behavior, but reverse, is observed in jaspilites adjacent to the contact. This shows the interaction between rocks during basalt intrusion. As highlighted before, the variation of physical properties between the ore canga (CM) and friable hematite (HF) is not visible in the automatic classification. However, analyzing the profiles within the sections, it is noted that the radioelement concentration is slightly superior in ore canga. In the ore package in the central portion of the F1051/N4WS drill hole (Fig. 17) there is a positive anomaly in the radioelement concentration, different from the behavior measured. But this anomaly appears in the geological description of the hole, raising doubts concerning its origin.

Section II can be divided by the normal fault mapped at the surface (Fig. 18). In the left portion of the fault we observed once again the individualization of chemical canga (CQ) and semiweathered mafic (MS) lithotypes. It was not possible to identify the intervals that correspond to the mineralized zones. The jaspilite again shows a dual behavior, with intervals of high and low magnetic susceptibility. However, unlike the previous section, low susceptibility jaspilites are located at the base of the section. The mafic rocks described as sills show the interaction haloin contact with jaspilite package. It suggests a contemporary interaction at the moment of intrusion. To the right of the normal fault, there is only a single drill hole that was sampled. It is composed basically of iron ore, with a small portion of jaspilite followed by mafic rock at the base. The profile analysis identifies two anomalous zones with high response in the total count channel of gamma spectrometry. Both are close and have, in part, similar depths to the previously mapped area in Section I. The description, however, does not indicate any particular feature corresponding to these anomalies.

Section III (Fig. 18), like its predecessors, shows similar behavior of the physical properties measured for the respective mapped lithologies. The low magnetic susceptibility jaspilites have a larger range values. Especially in the F1398/N4WS log and in the F1115/N4WS log, the transition to the high susceptibility jaspilite is marked by a shear zone coincident with the presence of mafic rocks, with a less intense halo as compared to those described previously. On the bottom of this section, the jaspilite and basalt interface is practically absent. In the geological description it is defined as abrupt. It is noteworthy that an anomalous zone in the total count values was not identified in the sampled jaspilites. Its depth coincides with the anomalies found in the previous sections. However, unlike Section III, the anomalous zones are Iocated within the iron ore.

The anomalous zones with higher radioelement concentrations are relevant because they are located to the right of the normal fault that cuts Sections I and II, and also because there is no corresponding feature in the local geological descriptions. Besides, it is present in both jaspilites and friable hematite. The fact that they are present not only in proto-ore but also in the iron ore itself is indicative that the anomaly is posterior to the mineralization process, making possible a correlation with the grade of the ore or even the identification of impurities.

Once identified and interpreted, the main characteristics of the iron ore, jaspilites and surrounding rocks as related to their magnetic susceptibility and $\mathrm{K}, \mathrm{U}$ and Th radioelement concentration, it is possible to make an integration between the data collected in situ and the other products used in this work. As discussed, there is a clear differentiation between jaspilites and mafic rocks and their alteration products, especially regarding values of radioelement concentration in the total count channel. The mafic rocks, semi-weathered mafics and chemical cangas present values of $191.50 \mathrm{cpm}, 179.11 \mathrm{cpm}$ and $191.10 \mathrm{cpm}$, and jaspilites along with friable hematite and ore canga, have average values of $158.34 \mathrm{cpm}, 149.56 \mathrm{cpm}$ and $160.11 \mathrm{cpm}$, respectively. Thus, the use of airborne gamma spectrometry data becomes relevant for a qualitative comparison between what is measured in surface and their corresponding response to the mapped lithologies.

For validation of this comparison it is interesting to use the geological information derived from other drilling data. The geological sections previously generated have been replaced for a more robust modeling, using the Oasis Montaj software, with the creation of lithology voxels in each section. The lithology voxel is nothing more than a 3D tool for gridding that uniquely integrates data from lithology using the three spatial dimensions. In this specific case, the kriging method was defined as the best conditioned statistical algorithm for data interpolation.

The goal here is, besides analyzing the behavior of the direct modeling, to visualize possible lateral variations that were mapped by the use of airborne gamma spectrometry survey data. 
The following figures show the products of modeling with the RGB ternary composition above them. The images are separated by a vertical offset in order to facilitate the visualization of both data.

The Section I voxel (Fig. 19) shows an apparent dip of the rocks to W-SW, in accordance with what has been mapped in the field. In addition, there are mafic rocks on the top, correlated to the Igarapé Cigarra Formation and mafic rocks at the base, interpreted as Paraupebas Formation. The ore is clearly concentrated at the top of the section and its presence declines as the depth increases. At the top we have the lateral variation from ore to chemical canga. It is worth noting the change in the gamma spectrometry response according to lithology. In areas defined as chemical canga, there is a tendency to have higher concentrations of the three radioelements (marked area), heading west. In the areas where ore canga outcrops there is a decrease in this response, indicated by dark tones, which are consistent with the low values found for the respective lithotype.

A similar pattern is expected for Section II (Fig. 19), where areas with higher concentrations of $\mathrm{K}, \mathrm{U}$ and $\mathrm{Th}$ in the ternary composition image are consistent with the mapped chemical canga. Between F1495/N4WS and F1348/N4WS drill holes, there is a region in a more greenish tone of $R G B$ composition, defined in the modeling as outcropping semi-weathered mafic rocks. In fact, statistical data indicate that, both thorium and uranium have a higher concentration within this lithotype when compared to potassium. The ore canga, linked directly to the ore, is indicated by the gamma spectrometry airborne survey data as the darkest area, connected to the low radioelement concentration.

Section III is the one that best reflects the correlation between the responses of the RGB ternary composition and the top of the drill holes data (Fig. 19). The most western portion (marked) shows the high radioelement concentration linked not only to chemical canga but also to semi-weathered mafics. Note the pattern of gamma-spectrometric response located at the top of the F1100/N4WS hole, distinct from that found in the previous sections. The RGB composition reflects an area richer in thorium as compared to the other radioelements. As expected the ore canga had a low response from the three radioelements. It is observed that the coverage of the ore canga is thin and followed in depth by semi-weathered mafics, unlike sections I and II. An interaction between the two lithotypes may be indicated by the anomalous behavior observed.

Given the correlation between the surface lithological information integrated with the gamma spectrometry airborne survey, the same comparison can be made for the petrophysical products in order to confirm the validity of the methods used for geological characterization of the N4WS body. The following figures illustrate Sections I, II and III with the interpretation of petrophysical zones superimposed by to image of RGB ternary composition, $\mathrm{K}, \mathrm{U}$ and Th (Fig. 20).

Superficial petrophysical zones are spatially coincident with the patterns defined by the gamma-spectrometric airborne survey for the respective lithotypes. The lateral variation of the radioelements concentration in the RGB ternary composition image follows the limits defined by the petrophysical zones of ore canga, with low radioelement concentration, and chemical canga, with high radioelement concentration. The top sections do not differ in relation to the petrophysical areas, in partial compliance with the proposed geological modeling, except for semi-weathered mafics, as previously discussed with respect to its similarity to the chemical canga. The absence of jaspilites and mafic rocks on surface, due to the severe weathering in the region, prevents the qualitative comparison with the airborne geophysical products for the purpose of confirmation with the data measured in the drill holes. The same situation is also true for the friable hematite, which displays at least its physical parameters correlated to the ore canga, facilitating a possible identification. The highlighted anomalous zones do not have correspondence on surface, which makes the airborne products inefficient for its characterization in the sampled area. It is important to note their presence in similar depths and their spatial continuity, regardless of the rock in which they are "hosted", indicative of a later onset of the diagenetic and mineralization processes.

\section{CONCLUSIONS}

The use of tools that allow the characterization of physical properties of iron formations and their consequent mineralization are still restricted to other mineral resources. However, with the magnetic susceptibility and radiometric signature identified, it was possible to define enough criteria to differentiate jaspilites, iron ore and surrounding mafic rocks. Such evaluation was even further extended, and a variation within jaspilites concerning magnetic susceptibility that hadn't been described geologically could be identified. The radioelement concentration, using total count, was also interesting for the identification of anomalous zones rich in $\mathrm{K}, \mathrm{U}$ and Th not only in iron ore but also in local jaspilites.

Both methods are interesting for direct application in the wells. Although it is not a tool for direct exploration, it was used to accurately map the stratigraphy and identify complex structures in a seemingly regular stratigraphy. 


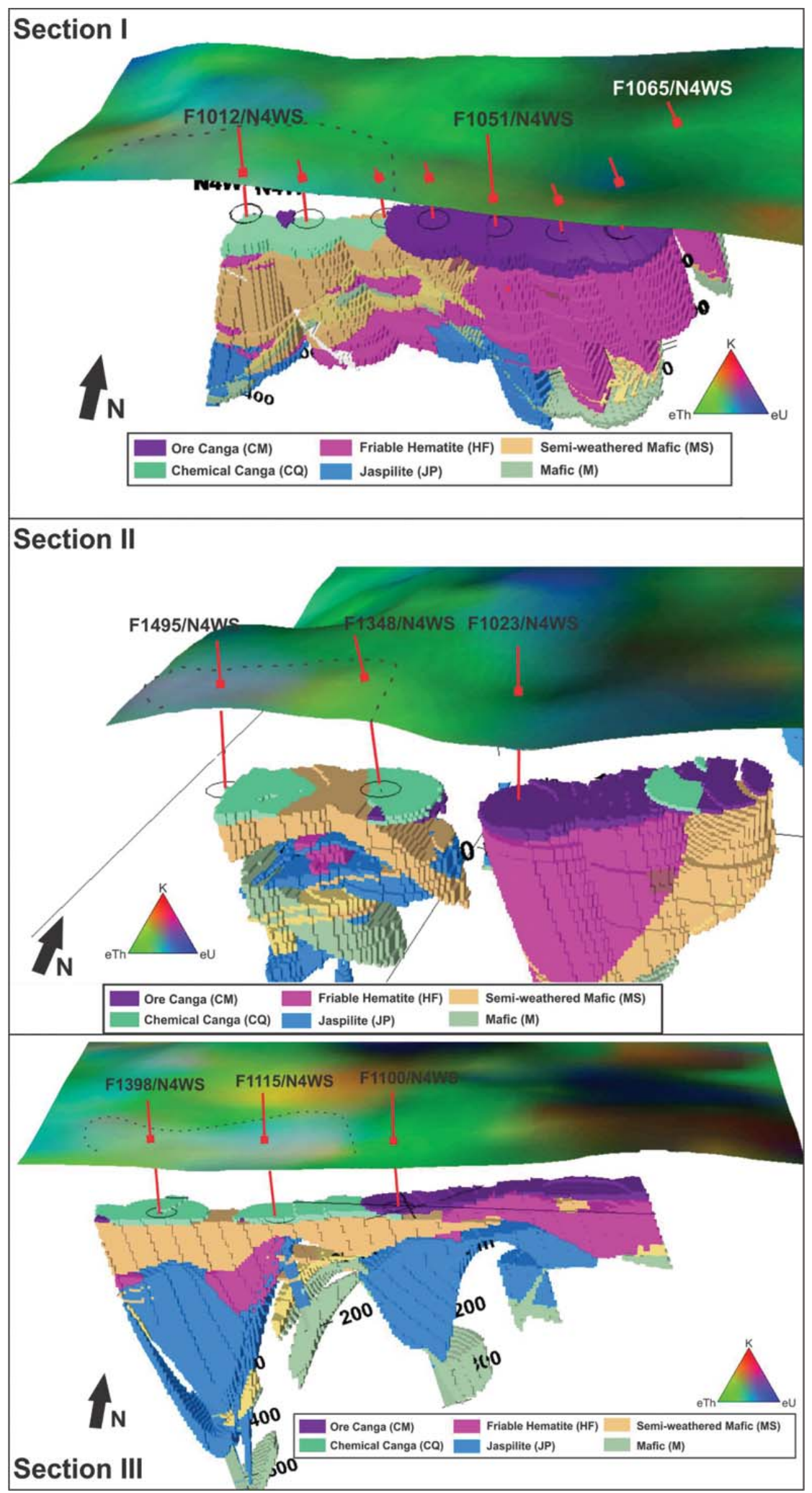

Figure 19 - Sections I, II and III. Voxel lithology overlaid with fused RGB (K, eU, eTh) ternary composition image with digital elevation model. 

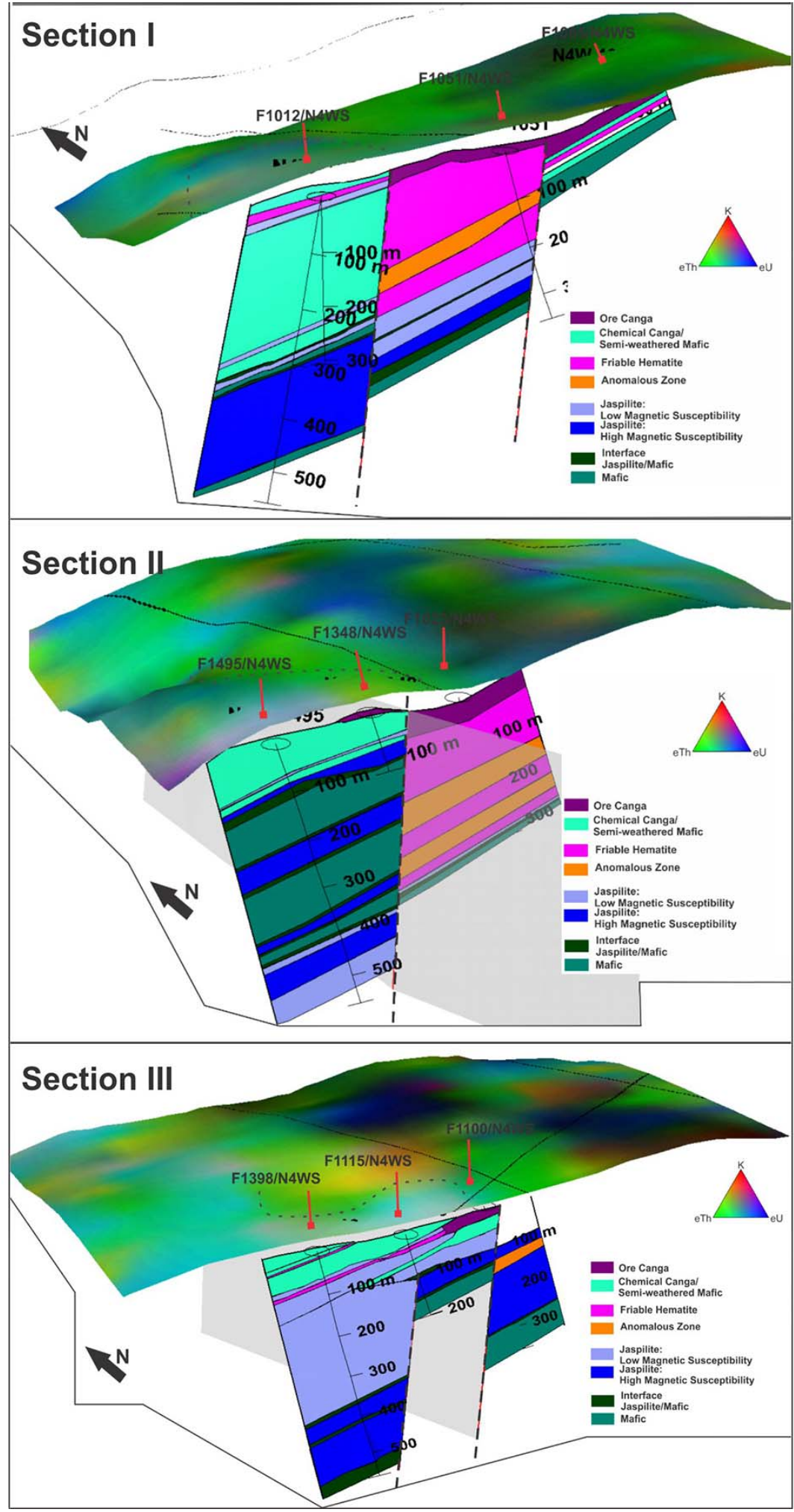

Figure 20 - Sections I, II and III. 'Petrophysical zones' overlaid with fused RGB (K, eU, eTh) ternary composition image with digital elevation model. 
It is important to note that the radiometric signature of iron formations "survives" the processes of more intense weathering and mineralization, indicating that the method can be applied not only during regional exploration but also in the mine environment. Regionally, the airborne gamma-spectrometric survey adds little to mapping in areas well known as it is the case within the Carajás Mineral Province. However, the integration of airborne data with the observed signature provided direct informations for mapping of greenfield areas for iron ore.

As a frontier to be explored, it is suggested that the development and consolidation of the methods could be used, with a focused use within the region of higher mineralization to increase knowledge of the ore behavior. Coupled with the use of physical properties, the development of a geochemical database and other physical parameters such as density in the collected samples will provide a better understanding of the origin of the observed variations within the object of the research. This will make it possible to identify richer iron zones and possible contaminants using only radiometric information and magnetic susceptibility. To assist regolith mapping in a detailed scale, it is suggested the acquisition of airborne gamma-spectrometric data with $125 \mathrm{~m}$ spacing for a better integration to field data.

With the association of the tools discussed in this paper and the developments suggested, we believe that it is possible to continue using the discussed methods in exploration work, allowing a better use of human and financial resources.

\section{REFERENCES}

ARAÚJO OJB \& MAIA RGN. 1991. Programa levantamentos geológicos básicos do Brasil. Projeto especial mapas de recursos minerais, de soIos e de vegetação para a área do Programa Grande Carajás: Subprojeto Recursos Minerais, Serra dos Carajás, Folha SB.22-Z-A. Brasília, Brazil, DNPM/Companhia de Pesquisa e Recursos Minerais-CPRM, 152 pp.

ASSIS LM. 2013. Geração de modelo exploratório para 0 minério de ferro da Província Mineral de Carajás através da integração de dados multifonte. M.Sc. dissertation, Instituto de Geociências, Universidade de Brasília, Brazil, 154 pp.

BEISIEGEL VR, BERNARDELLI AL, DRUMMOND NF, RUFF AW \& TREMAINE JW. 1973. Geologia e recursos minerais da Serra dos Carajás. Revista Brasileira de Geociências, 3: 215-242.

BEUKES NJ, GUTZMERJ \& MUKHOPADHYAY J. 2002. The geology and genesis of high-grade hematite iron ore deposits. Australasian Institute of Mining and Metallurgy, Publication Series, 7: 23-29.

BOYLE RW. 1982. Geochemical prospecting for thorium and uranium deposits. Developments in Economic Geology, 16: 71-78.
BRAGA MA. 2009. Aplicação de aerogradiometria gravimétrica 3D-FTG na prospecção de minério de ferro no Quadrilátero Ferrífero (MG) e modelagem 2D e 3D para estimativa de massa do depósito de ferro de N1 em Carajás (PA). UFRJ, Brazil, Ph.D. Thesis, p. 271.

BUBNER G, DENTITH M, DHU T \& HILLIS R. 2003. Geophysical exploration for iron ore in the Middleback Ranges, South Australia. Geophysical Signatures of South Australian Mineral Deposits, p. 29-46.

COSTA LP. 2007. Caracterização das sequências metavulcanossedimentares da porção leste da Província Mineral Carajás, Pará. M.Sc. dissertation, Belo Horizonte, Brazil, Universidade Federal de Minas Gerais, Departamento de Geologia, 113 pp.

COSTA JBS \& HASUI Y. 1997. Evolução geológica da Amazônia. In: COSTA MLC \& ANGÉLICA RS. (Coords.). Contribuição à Geologia da Amazônia. Belém, SBG-NO: p. 15-90.

DALSTRA H \& FLIS M. 2008. High-grade iron ore exploration in an increasingly steel-hungry world: The past, current and future role of exploration models and technological advances. Reviews in Economic Geology, 15: 393-409.

DALSTRA H \& GUEDES S. 2004. Giant hydrothermal hematite deposits with Mg-Fe metasomatism: A comparison of the Carajás, Hamersley, and other iron ores. Economic Geology, 99: 1793-1800.

DARDENNE MA \& SCHOBBENHAUS C. 2001. Metalogênese do Brasil, Editora Universidade de Brasília, Brazil, 392 pp.

DOCEGEO. 1988. Revisão litoestratigráfica da Província Mineral de Carajás. In: Proceedings of Congresso Brasileiro de Geologia, 35., Sociedade Brasileira de Geologia: Belém, Brazil, p. 11-54.

FIGUEIREDO E SILVA RC. 2004. Caracterização petrográfica e geoquímica de jaspilitos e minérios de ferro, Província Mineral Carajás, Pará: implicações para a mineralização de ferro. M.Sc. dissertation, Belo Horizonte, Brazil, Universidade Federal de Minas Gerais, Departamento de Geologia, 151 pp.

FLIS M. 2008. Advances in geophysics applied to the search for banded iron formation-related, high-grade hematite iron ore. Reviews in Economic Geology, 15: 381-392.

GIBBS AK, WIRTH KR, HIRATA WK \& OLSZEWSKI WS. 1986. Age and composition of the Grão Pará group volcanics, Serra dos Carajás. Revista Brasileira de Geociências, 16(2): 201-211.

GROSS GA. 1980. A classification of iron-formation based on depositional environments. Canadian Mineralogist, 18: 215-222.

HEIDER F, ZITZELSBERGER A \& FABIAN K. 1996. Magnetic susceptibility and remnant coercive force in grown magnetite crystals from $0.1 / \mathrm{xm}$ to $6 \mathrm{~mm}$. Physics of the Earth and Planetary Interiors, 93: 239-256. 
IAEA - International Atomic Energy Agency. 2003. Guidelines for radioelement mapping using gamma ray spectrometry data. Vienna, $173 \mathrm{pp}$.

KILLEEN PG. 1979. Gamma-ray spectrometric methods in uranium exploration - application and interpretation. In: HOOD PJ (Ed.). Geophysics and Geochemistry in Search for Metallic Ores. Geological Survey of Canada, Economic Geology Report, 31: 163-230.

LINDENMAYER ZG, LAUX JH \& TEIXEIRA JBG. 2001. Considerações sobre a origem das formações ferríferas da formação Carajás, Serra dos Carajás. Revista Brasileira de Geociências, 31(1): 21-28.

LINDENMAYER ZG, FLECK A, GOMES CH, SANTOS ABZ, CARON R, PAULA FC, LAUX JH, PIMENTEL MM \& SARDINHA AS. 2005. Caracterização geológica do Alvo Estrela (Cu-Au), Serra dos Carajás, Pará. In: MARINI OJ, QUEIROZ ET \& RAMOS BW (Eds.). Caracterização de depósitos minerais em distritos mineiros da Amazônia. DNPM/CTMineral/FINEP/ADIMB, Brasília, Brazil, p. 157-226.

LOBATO LM, ROSIÈRE CA, SILVA RCF, ZUCCHETTI M, BAARS FJ, SEOANE JCS, RIOS FJ, PIMENTEL M, MENDES GE \& MONTEIRO AM. 2005a. A mineralização hidrotermal de ferro da Província Mineral de Carajás - Controle estrutural e contexto na evolução metalogenética da província. In: MARINI OJ, QUEIROZET \& RAMOS BW (Eds.). Caracterização de depósitos minerais em distritos mineiros da Amazônia: DNPM/CTMineral/FINEP/ADIMB, Brasília, p. 25-92.

LOBATO LM, FIGUEIREDO E SILVA RC, ROSIÉRE CA, ZUCCHETTI M, BAARS FJ, PIMENTEL MM, RIOS FJ, SEOANE JCS \& MONTEIRO AM. 2005b. Hydrothermal origin for the iron mineralization, Carajás Province, Pará state, Brazil. In: Iron Ore 2005, The Australian Institute of Mining and Metallurgy, Publication Series, 8: 99-110.

LOVBORG L \& MOSE E. 1987. Counting statistics in radioelement assaying with a portable spectrometer. Geophysics, 52(4): 555-563.

MACAMBIRA JB. 2003. 0 ambiente deposicional da Formação Carajás e uma proposta de modelo evolutivo para a Bacia Grão Pará. Ph.D. Thesis, Instituto de Geociências, Universidade Estadual de Campinas, Brazil, 217 pp.

MACAMBIRA JB \& SCHRANK A. 2002. Químio-estratigrafia e evolução dos jaspilitos da Formação Carajás (PA). Revista Brasileira de Geociências, 32(4): 567-578.

MACAMBIRA JB, RAMOS JFF, ASSIS JFP \& FIGUEIRAS AJM. 1990. Projetos Serra Norte e Pojuca, Relatório final. Convênio DNPM/ DOCEGEO/UFPA, Belém, Brazil.

MACHADO N, LINDENMAYERZ, KROGH TE \& LINDENMAYERD. 1991. U-Pb geochronology of Archean magmatism and basement reactivation in the Carajás area, Amazon Shield, Brazil. Precambrian Research, 49: 329-354.
MEIRELLES MR. 1986. Geoquímica e petrologia dos jaspilitos e rochas vulcânicas associadas, Grupo Grão-Pará, Serra dos Carajás, Pará. M.Sc. dissertation, Instituto de Geociências, Universidade de Brasília, Brazil, $171 \mathrm{pp}$.

MEIRELLES MR \& DARDENNE MA. 1991. Vulcanismo basáltico de afinidade shonshonítica em ambiente de arco arqueano, Grupo Grão Pará, Serra dos Carajás, Pará. In: Resumos Expandidos dos Anais Congresso Brasileiro de Geoquímica, Brazil, 4: 131-132.

PIDGEON RT, MACAMBIRA MJB \& LAFON JM. 2000. Th-U-Pb isotopic systems and internal structures of complex zircons from an enderbite from the Pium Complex, Carajás Province, Brazil: evidence for the ages of granulite facies metamorphism and the protolith of the enderbite. Chemical Geology, 166: 159-171.

PIRES ACB. 1995. Identificação geofísica de áreas de alteração hidrotermal, Crixás-Guarinos, Goiás. Revista Brasileira de Geociências, 25(1): $61-68$.

RESENDE NP \& BARBOSAALM. 1972. Relatório de pesquisa de minério de ferro, distrito ferrífero da Serra dos Carajás, estado do Pará. AMZA, Relatório Final de Pesquisa, v. 1, texto, 248 pp, v. 2, mapas e seções geológicas, p. 119.

ROSIÈRE CA, SEOANE JCS, BAARS FJ \& LOBATO LM. 2004. Estruturação da província de Carajás e sua influência na mineralização de ferro, PA. In: ADIMB, Simpósio Brasileiro de Exploração Mineral, Ouro Preto, CD-ROM.

SILVA GH, LEAL JWL, SALUM OAL, DALL'AGNOL R \& BASET MAS. 1974. Esboço geológico de parte da Folha SC.21 Juruena. In: Congresso Brasileiro de Geologia, 29, Porto Alegre. Anais... Porto Alegre, Brazil: SBG. 4: 309-320.

TEIXEIRA JBG. 1994. Geochemistry, petrology, and tectonic setting of the archean basaltic and dioritic rocks from the N4 Iron deposit, Serra dos Carajás, Pará, Brazil., Boston, 1994. Ph.D. Thesis, The Pennsylvania State University/Department of Geosciences, 176 pp.

TOLBERT GE, TREMAINE JW, MELCHER GC \& GOMES CB. 1971. The recently discovered Serra dos Carajás iron deposits, Northern Brazil. Economic Geology, 7: 985-994.

TRENDALL AF, BASEI MAS, DE LAETER JR \& NELSON DR. 1998. Ion microprobe zircon, U-Pb results from the Carajás area of the Amazon Craton. Journal of South American Earth Sciences, 11: 265-276.

VASQUEZ ML, ROSA COSTA LT, SILVA CMG \& KLEIN EL. 2008. Geologia e recursos minerais do estado do pará: sistema de informações geográficas - SIG: texto explicativo dos mapas geológico e tectônico e de recursos minerais do estado do Pará. In: VASQUEZ ML \& ROSA-COSTA LT (Orgs.). Escala 1:1.000.000. Belém, Brazil. CPRM, 2008. 
ZACCHI ENP, SILVA AM \& ROLIM VK. 2010. Análise integrada de dados multifonte e sua aplicação no mapeamento geológico das formações ferríferas da Serra de Itapanhoacanga, Alvorada de Minas, MG. Brazilian Journal of Geophysics, 28(4): 643-656.

ZUCCHETTI M. 2007. Rochas máficas do Supergrupo Grão Pará e sua relação com a mineralização de ferro dos depósitos N4 e N5, Carajás,
(PA). Ph.D. thesis, Belo Horizonte, Brazil, Universidade Federal de Minas Gerais, Departamento de Geologia, 125 pp.

ZUCCHETTI M \& LOBATO LM. 2004. Alteração hidrotermal a ferro das rochas máficas associadas aos depósitos de ferro N4 e N5, Província Mineral de Carajás, PA. In: ADIMB, Simpósio Brasileiro de Exploração Mineral, Ouro Preto, CD-ROM.

Recebido em 22 setembro, 2014 / Aceito em 26 julho, 2016

Received on September 22, 2014 / Accepted on July 26, 2016 